\title{
ERKEN ORTAÇAĞLARDA TEBRIZ
}

\author{
Abdulhalik Bakır* - Ahmet Altungök**
}

\begin{abstract}
Özet
Tarih boyunca çok sayıda depreme ve istilaya sahne olan Tebriz şehri bütün bu olumsuz olaylara rağmen günümüze kadar gelmeyi başarabilmiş ender Türk şehirlerindendir. Ne zaman kurulduğu tam olarak bilinmese bile kurulduğu ilk zamanlardan itibaren Türklerin yaşadığı bir şehir olma vasfını sürekli olarak korumuştur. Tebriz şehri, Antik Yunanlıların Atropaten; Antik İranlıların ise Adurbadegan dedikleri Azerbaycan topraklarının merkezidir. Erken Ortaçağların küçük, fakat dini ve askeri açıdan etkin bir şehri olan Tebriz kenti; Kafkaslar, Anadolu ve İran toprakları arasında önemli bir kavşakta yer almaktadır. Bu özelliğinden dolayı Tebriz şehri; Hazar, Bizans ve Sâsânî Devletleri arasında sürekli olarak çekişme konusu olmuştur. Askeri ve dini yapısının yanında ticaret şehri olan Tebriz, aynı zamanda Sâsânî Devletinin önemli bir kültür merkezidir. Tebriz şehri, Sâsânîlerin Bizans ve Kafkas kavimlerine yönelik olarak kullanmış olduğu önemli bir askeri üs durumundaydı. Azerbaycan toprakları tarih boyunca birçok milletin egemenliği altına girmesine rağmen bu ülkenin merkezi olan Tebriz şehri çok sayıda istila girişimine rağmen bir Türk şehri olma vasfını koruyabilmiştir.
\end{abstract}

Anahtar sözcükler: Azerbaycan, Sâsânî, Tebriz, Ganzak, Atropaten.

\section{Abstract \\ Tabriz City in the Early Medieval Times}

Throughout history, the scene of many earthquakes and invasions in Tabriz despite all these negative events have managed to come up to the present is one of the few Turkish cities. It wasn't known exactly when it was established from the start, not purport to be a city inhabited by Turks remained constant. Tabriz city, the ancient Greeks Atropatena; the ancient Iranians say the Adurbadegan is the center of the territory of Azerbaijan. Early Medieval small but Tabriz city an effective for religious and military; Caucasus, Anatolia, and Iran is an important part of the territory. Due to this feature in Tabriz; between of Caspian, Byzantine and Sassanid states has been the subject of constant contention. Tabriz was a trading centre besides a military and religious important, also important cultural city for Sassanid. Addition to Tabriz city important religion and cultural status, Sassanid Empire used an important military base for Byzantine and Caucasian. Throughout history, the territory of Azerbaijan although a lot of folks do not fall under the domination of the city is the center of this country Tabriz despite numerous attempts invasion the quality of being able to maintain a Turkish city.

Keywords: Azerbaijan, Sassanid, Tabriz, Ganzac, Atropatena.

\footnotetext{
*Prof. Dr, Bilecik Üniversitesi Fen-Edebiyat Fakültesi Tarih Bölümü.

*** Yrd. Doç. Dr, Bilecik Üniversitesi Fen-Edebiyat Fakültesi Tarih Bölümü.
} 


\section{Giriş}

Tebriz şehrinde Erken Ortaçağlara ait herhangi bir mimari kalıntının mevcut olmamasının sebebi, bu şehrin depremler ve korkunç istila faaliyetleri sonucunda birkaç defa yerle bir olmasından kaynaklanmaktadır. Tebriz şehri, tarih boyunca sık sık yıkıcı depremlere maruz kalmış ve bunların en yıkıcı olanları da Erken Ortaçağlarda yaşanmıştır. Bu sebeplerden dolayı, şehir yaşadığı her deprem ve istiladan sonra, mimari yapısı ile beraber sahip olduğu zenginliklerin çoğunu kaybetmekteydi. Tebriz şehri, deprem felaketlerinin ardından bazı zamanlarda terk edilmiş ve şehir halkı, yakınlarındaki kasabalara göç etmiştir. Bunun sonucunda da zaman zaman koca şehir, küçük bir köy haline gelmiştir ${ }^{1}$. Şunu açık bir şekilde söylememiz gerekir ki, Tebriz'in Erken Ortaçağlardaki durumu ile ilgili bilgilerimiz sınırlıdır. Elimizdeki veriler, bu şehrin çok eski çağlarda kurulmuş olduğunu göstermiş olsa da Tebriz'in tahrip olması nedeniyle buranın siyasi, sosyal ve fiziki yapısıyla ilgili bilgi günümüze kalmamıştır. Şehrin tarihiyle ilgili acı gerçeklerden birisi de, aynı nedenlerden ötürü, mimari yapısının günümüze kadar gelmemiş olmasıdır².

Tebriz şehri, Sakalardan itibaren günümüze kadar Türklerin meskûn olduğu şehirlerin en eski olanlarından bir tanesidir. Burası, sekiz yüz yıllık bir zaman zarfında Saka, Med, Pers, Part, Selevkos ve Sasanî devletlerinin elinde kalmış ve Sâsânîlerin yıkılmasıyla birlikte Arapların eline geçmiştir ${ }^{3}$. Bu devletlerin Tebriz'e hâkim olduğu dönemlerde bile buradaki Türk varlığı devam etmiştir. Aynı zamanda Erken Ortaçağlara kadar sürekli olarak el değiştiren bu şehre, çok farklı kavimler gelerek yerleşmişlerdi ve bundan dolayı şehir nüfusu farklı demografik özellikler göstermekteydi. MS. 642'deki Arap hâkimiyetinden sonra şehir yoğun olarak Araplaşmaya başlamıştır. Şehirdeki yoğun Arap varlı̆̆ 1 , Abbasilerin yıkılmasına kadar devam etmiş ve şehir, 11. yüzyıldan itibaren Oğuz göçleriyle tekrar Türkleşmeye başlamıştır.

Kurulduğu ilk çağlardan itibaren Tebriz'de, Saka, Manna, Kaspi, Hun, Ogur, Sabar, Avar ve Hazar gibi Turanî kavimler ile Kimmer, Med, Pers, Part, Alan gibi Aryen uluslar, iç içe yaşamışlardır. Erken Ortaçağların başlarında Saka, Manna ve Kaspi unsurunun inkişafı ile bugünkü Azeri toplumu oluşmaya başlamış ve Azeriler, şehir halkının çoğunluğunu oluşturarak şehrin Türklüğünün devamını sağlamışlardır. Tebriz şehrinin konumu, İran tarihinin önemli bir yönünü oluşturmaktadır ${ }^{4}$. Çünkü burası, Sâsânî imparatorluğu üzerinde özellikle askeri, ekonomik ve dini açıdan önemli bir rol üstlenmekle

\footnotetext{
${ }^{1}$ Yakut (Trz), s.15.

${ }^{2}$ Bosworth 1968, s.33.

${ }^{3}$ İstahrî 1997, s.108.

${ }^{4}$ Houtsma 1993; Wensinck 1993, s.426.
} 
kalmamış, Sâsânî siyasi tarihini de önemli ölçüde etkilemiştir ${ }^{5}$. Sâsânî egemenliğinde kalan Tebriz şehri, Sâsânî siyasi tarihi ile beraber gelişim göstermiştir ${ }^{6}$. Şehirdeki önemli Türk varlığına rağmen, halkın büyük kısmının İran'ın milli inancı olan Zerdüştlüğ $e^{7}$ bağlı olması ve bu inancın, şehrin demografik, mimari, ticari ve kültürel yapısına hâkim olması sebebiyle bu şehir tipik bir Erken Ortaçağ İran şehri görünümüne bürünmüştür.

\section{Tebriz'in Antik Dönemdeki Adları}

Şehrin adı, ilk olarak II. Sargon'un yazitlarında Tarmakisa olarak geçmektedir ${ }^{8}$. Eski Roma kaynaklarında Tebriz kenti Tauris, Tavres, Ganzak, Thebermais ve Beramais şeklinde isimlendirilmiştir ${ }^{9}$. Bununla beraber, Ganzak ve Thebermais'in Urumiye Gölü kenarında Tebriz şehrine bağlı iki kasaba olduğu da ifade edilmektedir ${ }^{10}$. İlkçağ tarihçilerinden Strabon da Tebriz şehri için Gazakon tabirini kullanmıştır ${ }^{11}$. Şehrin asıl adının, Ganzaka veya Gazaka olduğu ve Ermenilerin burayı ele geçirmelerinden sonra adının Tavrez ve Tauris şeklini aldığını söyleyen tarihçiler de bulunmaktadır ${ }^{12}$. Ayrıca tarihi metinlerde geçen Ganzak veya Gazaka ile Thebermais kentlerinin Tebriz ile ilgili olduğunu söyleyen tarihçiler çoğunluktadır ${ }^{13}$. Mesela bu tarihçilerden Drapeyron ve Charles le Beau, Ganzak ve Tebriz'i aynı şehir olarak tanıtmışlardır ${ }^{14}$. Partlar döneminde Adurbadegan topraklarının başkenti olan Ganzak'ın bir deprem

\footnotetext{
${ }^{5}$ Morony 1976, s.14.

${ }^{6}$ Akiner 1983, s.105; Sâsânîler'in Ermenileri etkisiz hale getirmelerinden sonra Tebriz şehri, önce Romalılar, daha sonra da Bizans ve Hazarlar ile Sâsânîler arasındaki savaşların odak noktası haline gelmiştir. Reisneya (Trz), s.445.

${ }^{7}$ Gündüz 2003, s.279: "Mecûsîlik, Zerdüşt'ün tebliğ ettiği, monoteist ve teoloji içeren inanç ve düşüncelerin eski İran inanç ve gelenekleriyle mezcedilmesinden oluşan bir dindir. Sâsânîler döneminde yönetici sınıfla da yakından irtibatlı olan rahip sınıfı Mecî'den (Mecûs) hareketle, İslâm kaynaklarında Mecûsîlik, Batı kaynaklarında ise Zerdüşt'ün isminden dolayı Zoroastrianism veya Ahura Mazda isminden hareketle Mazdeizm olarak adlandırılır. Ayrıca ateş kültüyle ilgili inanç ve ritüelleri sebebiyle Ateşperestlik adıyla da bilinir.”. Geniş bilgi için bkz. Ebu Yusuf 1982, s.296-300; el-Âlûsî, (Trz.), s.348-357; Hamidullah 1985, s.139-156.

8 Diakonof 1985, s.86. Tarma" sözcüğünün, "1s1/ateş" sözcüğünü vermesi açısından önemlidir. Asur yazıtlarında Tebriz şehri için, "ateş" ve "1sı" sözcüklerini anımsatan "Tarma/Therma" denilmesi, bu kavramı Aryen dillerini konuşan kavimlerden aldıklarını göstermektedir. Bu durum Tebriz şehrinin adının İlkçağlardan bu yana "ateş" sözcüğü ile ifade edilmiş olduğunu göstermektedir. Tarmakisa kenti için bkz. Pınarcık 2012, s.266.

${ }^{9}$ Reisneya (Trz), s.494; Christensen 1993, s.211; Syme ve Birley 1995, s.35.

${ }^{10}$ Minorsky 1337hş, s.8; Schippmann 1989, s.224.

${ }^{11}$ Smith 1833, s.144.

12 Rawlinson 1841, s.109; Mignan 1834, s.577.

${ }^{13}$ Arrowsmith ve Nicolay 1856, s.531; Rawlinson 1841, s.106.

${ }^{14}$ Reisneya (Trz), s.496.
} 
sonucunda yıkılmasından önceki Tebriz'in ilk kurulduğu yer olması ihtimali üzerinde de durulmaktadır ${ }^{15}$. Tebriz şehrinin önemini kaybettiği dönemlerde Adurbadegan eyaletinin ağırlık merkezinin Ganzak'a kaydığı ve Tebriz'in eski önemine kavuşmasından sonra da ă̆ırlık merkezinin tekrar Tebriz şehrine döndüğü de tahminler arasında bulunmaktadır ${ }^{16}$.

Tebriz'in adı Asur yazıtlarında Tarmakisa olarak geçmesi nedeniyle Saka İmparatoru Alper Tunga'nın kızı Tomuris'in veya Massaget kraliçesi Tomris'in adıyla da ilgili olabileceği ihtimalini beraberinde getirmiştir ${ }^{17}$. Aslında Tebriz kentinin adını, Saka-Pers savaşları sırasında almış olması kuvvetli bir ihtimaldir. Alper Tunga ${ }^{18}$ komutasındaki Saka Türklerinin Kafkaslar ve Doğu Anadolu'ya egemen oldukları dönemde, Perslerle savaşlarının merkezi durumunda olan Tebriz şehri, sahip olduğu bu adı, bu sırada almış olması da mümkündür ${ }^{19}$. Ahamanişler döneminin başlarında Kafkaslar üzerindeki SakaPers mücadelesinden dolayı Tebriz kenti, iki kavim arasında şiddetli savaşlara sahne olmuştur. $\mathrm{Bu}$ savaş sırasında, Göktürklerin de çok sık uygulamış oldukları, nefte batırılmış okların düşman birlikleri üzerine yağdırılması taktiğinin geçmişinde Saka Türkleri bulunmaktadır ${ }^{20}$.

Birçok tarihi kaynak, Alper Tunga'nın İran ve Azerbaycan topraklarının çoğunluğuna egemen olduğunu ve bu bölgelerde birçok şehir ve kaleyi onarıp kurdurduğunu ifade etmektedir ${ }^{21}$. Alper Tunga ile Pers hükümdarı Keyhüsrev arasındaki savaşlar, eski İran kaynaklarında geniş yer almaktadır. Özellikle fillerle donatılmış Pers ordularına karşı Saka birliklerinin düşman üzerine yağdırmış oldukları ateşli oklar, fil birliklerini panikleterek düşmana önemli kayıplar verdirmekteydi. Persler, düşmanlarının üzerlerine yağdırmış oldukları

${ }^{15}$ Christensen 1993, s.208.

${ }^{16}$ Vaux 1900, s.304.

${ }^{17}$ Zehtabî (Trz), s.362.

18 İranlıların kendisine Afrasyab dedikleri Alper Tunga, Tûr'un soyundan gelen bir Oğuz hükümdarı olup, Türkistan ile beraber İran, Hindistan, Rum ve Rus ülkelerini ele geçirmiş güçlü bir Turan imparatorudur. Bkz. Ünal 1975, s.17; Öztuna 1977, s.25. Alper Tunga hakkında daha geniş bilgi için bkz. Aksoy 2002, s.560.

19 Anılan savaşların tarihi M.Ö. VII. yüzyıla kadar uzanmaktadır. Bu dönemde Orta Asya merkezli Saka Türklerinin Kafkaslara akın ederek Perslerle mücadele ettikleri ve Doğu Azerbaycan, Doğu Anadolu ve Suriye topraklarını ele geçirerek Azerbaycan toprakları üzerinde yerleştikleri ifade edilmektedir. Bkz. Togan 1942, s.87; Herodotos 1991, s.196.

20 Orta Asya'ya giden ilk Bizans elçisi olan Zemarkhos, Göktürkler hakkında imparatoruna raporunu sunarken "Bunlar eskiden Sakaydılar, fakat şimdi Göktürk olmuşlar" dediği rivayet edilmektedir. VI. yüzyıl tarihçilerinden Menandros da Türklere eskiden Saka dendiğini ifade etmektedir. Konu için bkz. P'yankov 2002, s.615. Ayrıca Zemarkhos, Göktürk kağanının İskit alfabesiyle yazmış olduğu mektubu Bizans imparatoruna takdim etmiştir. Bkz. Ligeti 1998, s.62.

${ }^{21}$ Abdurrahman 2004, s.8. 
bu ateşli oklardan dolayı onların buradaki merkezleri olan Tebriz şehrine ateş akıtan/döken/yağdıran anlamında bu ismi vermiş olmaları güçlü bir ihtimaldir.

Diğer bir görüsse göre ise, Tebriz kentinin yakınındaki sönmüş bir volkanik dağ olan Sehend dağının geçmişteki lav püskürme faaliyetlerinden dolayı, şehrin adını dağdan aşağıya doğru akan lav akıntılarından dolayı "ateş saçan" anlamına gelen "tab-riz" şeklinde almıştır ${ }^{22}$. Fakat bu dağın volkanik faaliyetlerinin eski çağlarda kesilmiş olması ve o dönemlerde bu bölgede İran dillerini konuşan toplulukların bulunmaması da bu ihtimali zayıf kılmaktadır ${ }^{23}$. Başka bir görüşe göre, Eşkânîler döneminde Kafkaslar üzerinden Azerbaycan topraklarına akın eden Türk toplulukları Tebriz şehrine bu ismi verseler de kentin, Tebriz adını Ahamanişler döneminin başlarında aldığına yönelik ipuçları da vardır ki bu da yaklaşık olarak MÖ birinci bin yılın ikinci yarısına, Sakaların, Kafkasya'ya egemen oldukları döneme denk gelmektedir ${ }^{24}$.

Tebriz şehrinin adı, Ortaçağ İslam coğrafyacılarının eserlerinde, "Tibriz", Bizans kaynaklarında "Tavres", Ermeni kaynaklarında ise "Davrez" olarak geçmektedir $^{25}$. Tebriz şehrinin, adını nereden ve nasıl aldığı konusu önemlidir. Farsça ateş akıtan, ateş saçan anlamında; "tab" (ateş) ve "rihten" (dökmek) kökünden gelen "riz" (dökülen) sözcüklerinin bileşimi sonucunda ortaya çıktığına inanılan Tebriz sözcüğünün bu adını şehrin etrafindaki kaplıcalardan aldığına inanılır ${ }^{26}$. Bir rivayete göre ise Abbasî halifesi Hârûnu'r-Reşî̀d'in eşi Zübeyde'nin yakalanmış olduğu ateşli sıtma hastalığ 1 sonucunda, bu şehrin latif havası nedeniyle yakalandığ hastalıktan kurtulmasından sonra ikamet ettiği bu bölgede bir şehir kurulmasını ve şehrin adının da "ateş giderici" anlamında "Tebriz" olarak konulmasını istediğini söyleyenler de vardı2 ${ }^{27}$. Bunun yanında, Zübeyde'nin; tıbbi açıdan gelişmiş bir şehir olan Tebriz şehri doktorlarının yüksek maharetiyle hastalıktan kurtulması üzerine, hastalık gideren doktorluk (tıbb/tıp) anlamında $t \imath b b$ riz olarak isimlendirildiği de söylenmektedir ${ }^{28}$. Bundan dolayı Arap coğrafyacıları, bu şehrin ismini, buna yakın olarak tibriz şeklinde telaffuz etmektedirler. Fakat Zübeyde'nin, bu şehrin ismini neden Arapça değil de Farsça isimlendirdiği konusu, şehrin adını bu dönemde almış olduğuna yönelik bir çelişkiyi de beraberinde taşımaktadır ${ }^{29}$. Bunun yanında Tebriz

\footnotetext{
${ }^{22}$ Dumper, 2007, s.339.

${ }^{23}$ Diakonof 1985, s.56.

${ }^{24}$ Minorsky, 1337hş, s.7; Minorsky 1965, s.83. Cavendish 2007, s.51-52.

${ }^{25}$ Rawlinson 1841, s.109; Dumper 2007, s.339; Minorsky 1337hş, s.7.

${ }^{26}$ Fisher 1978, s.303.

${ }^{27}$ Oseley 1825, s.414; Smith 1883, s.144; Minorsky vd. 2007, s.487.

${ }^{28}$ Elgood 2010, 311.

${ }^{29}$ Strange 2011, s.161. Zübeyde'nin bir köy olan bu şehri tekrar inşa ettiği kesin olmakla beraber ismini onun koymuş olması sadece güzel bir benzetmeden ibarettir. Bkz. Oseley 1825, s.412-5.
} 
sözcüğünün anlamına Evliya Çelebi gibi “sıtma giderici”, "sıtma dökücü" şeklinde anlamlar yükleyenler de olmuştur ${ }^{30}$. Tebriz şehrinin, ateş tapınaklarının çokluğuyla ünlü olduğu Azerbaycan satraplığının başkenti olmasından dolay1 şehrin adının bu ateş tapınaklarıyla ilgili olduğu da söylenmektedir ${ }^{31}$.

\section{Tebriz'in Coğrafi Yapısı}

Tebriz kenti, İran'ın dördüncü büyük kenti olup ülkenin kuzey batısında bulunan Sehend Dağının kuzey yamaçlarında kurulmuştur. Kentin içerisinde bulunduğu ova, Urumiye gölüne doğru alçalan bir araziden ibarettir. Bu ova, Sabelan dağının güney batısından başlayıp, Karacadağ'ın batısına kadar uzanır. Tebriz şehri, Sabelan ve Sehend volkanik dağlarından akan derelerin beslediği Acıçay'ın kolları tarafından biriktirilmiş verimli bir ova üzerinde inşa edilmiştir $^{32}$. Herodot, yaşadığ 1 dönemde, bu nehrin ikiye ayrılarak bir kolunun Tebriz ovasını ikiye ayırdığını ve şehrin bu kolun iki tarafına yayıldığını ifade etmiştir $^{33}$. Şehrin üzerinde kurulmuş olduğu arazi, yaklaşık olarak deniz seviyesinden 1350 ila 1500 metre yüksekliktedir. Şimdiki şehir, Sabelan dağından gelen Acıçay'ın bir kolu olan Mehran çayının etrafinda bulunmaktadır. Bu nehir birçok küçük koluyla birlikte şehrin muhtelif yerlerini sulamaktadır ${ }^{34}$. İlk kurulduğu çağlarda Tebriz şehrinin ilk sakinlerinin şehrin yakınlarındaki Yanıktepe'nin yüksek yamaçlarındaki oyuklarda yerleşmiş oldukları arkeolojik kazılar sonucunda ortaya çıkarılmıştır ${ }^{35}$. Şehir, kimi zaman Urumiye gölünün batı kıyılarına yakınına doğru kaymışsa da farklı dönemlerde depremlerle yıkıldıktan sonra yine eski temelleri üzerine kurulmuştur ${ }^{36}$.

Tebriz kenti, sert karasal bir iklime sahiptir. Yazları sıcak ve kurak kışları ise çok sert geçer. Öyle ki Bizans İmparatoru Herakleios, Hazar Türkleri ile yapmış olduğu bir ittifak neticesinde, Sâsânî hükümdarı II. Hüsrev'i ele geçirmek üzere kendisini takip ettiği sırada Tebriz şehrine gelir, fakat II. Hüsrev kaçarak Sâsânî başkenti Medâ'in'e çekilir. Yağmakta olan şiddetli kardan dolayı Herakleios, 24 Şubat'tan 4 Nisan'a kadar Tebriz'de kalmak zorunda kalır $^{37}$. Tebriz şehrinin etrafında, yerin kırıklı yapısından dolayı çok sayıda kaplıca bulunmaktadır. Etrafinın sulak olmasından hareketle, Sâsânîler'den önceki dönemde, şehrin çevresine içi su dolu hendekler kazılmak suretiyle

\footnotetext{
${ }^{30}$ Minorsky 1965, s.83.

${ }^{31}$ Tyrwhitt 1868, s.58.

${ }^{32}$ Rawlinson 2002, s.7; Dumper 2007, s.339; Strange 2011, s.161-163.

${ }^{33}$ Herodotos 1991, s.449.

${ }^{34}$ Strange 2011, s.162; Minorsky 1965, s.82.

${ }^{35}$ Bilgili, 2011, s. 219.

${ }^{36}$ Dumper 2007, s.339.

${ }^{37}$ Reisneya (Trz), s.694.
} 
düşmana karşı korunduğu Asur kralı II. Sargon'un yazıtında belirtilmektedir ${ }^{38}$. Asurluların Tebriz şehrini ele geçirdikleri dönemde, şehir düz bir ovanın içerisinde kurulu olduğundan etrafı surlarla çevrilmişti ve bu surların etrafında da hendekler kazılmıştı ${ }^{39}$.

\section{Tebriz'in Tarihsel Geçmişi}

Azerbaycan toprakları üzerinde yapılmış olan arkeolojik kazılar, Paleolitik döneme ait ilk insan izlerine Urumiye gölü civarında ve Tebriz'in güney yamacında kurulu olduğu Sehend dağındaki mağaralarda ve açık yerlerinde rastlanılmıştır. MÖ. 6000'li yıllara uzanan Neolitik dönem iskân yerlerinde, tarıma dayalı yerleşik hayata geçildiğine dair izler bulunmuştur. $\mathrm{Bu}$ veriler de Tebriz şehrinin Ön Asya'daki en eski yerleşim yerlerinden birisi olduğunu göstermektedir ${ }^{40}$. Şehirdeki arkeolojik kazıların altı bin yıl öncesine ait izler taşıması șehrin İskender istilasından sonra kurulmuş olabileceği olasılığını zayıf kılmaktadır ${ }^{41}$. İranlı tarihçi Hamaçî, daha da ileri giderek Tebriz şehrinin Aryenlerin İran topraklarına gelmesinden çok daha önce kurulmuş bir şehir olduğunu iddia eder ${ }^{42}$. Zehtabî; Tebriz adına, II. Sargon kitabelerinde rastlanılmasından hareketle şehrin bu tarihlerden önce kurulduğunu iddia etmektedir. Yazar bu görüşünü, Tarmakisa şehrinin, Tebriz şehri olduğunu, yazıtlarda belirtilen şehrin özelliklerinden hareketle ileri sürmektedir ${ }^{43}$. Minorsky ve Diakonof da Asur kralı II. Sargon'un Urartular üzerine yapmış olduğu bir sefer sırasında, Urumiye gölünü geçerek MÖ. 714 y1lında Tebriz şehrini aldığını söylemektedirler ${ }^{44}$.

MS. 4. yüzyılda Roma ordusuyla beraber Adurbadegan topraklarına gelen A. Marcellinus ile MS. 6. yüzyılda Tebriz'e ziyarette bulunan Procopius bu şehirden Gazaka şeklinde bahsetmişlerdir ${ }^{45}$. Ayrıca Eşkânîlerin yıkılmasından sonra kısa bir dönem için buraya hâkim olan Ermeniler, Tebriz şehri ve bu şehre bağlı diğer kentlerin hepsini Kandsag Adurbadgan şeklinde adlandırmışlardır ${ }^{46}$. Ritter, Tebriz şehrinin eski bir Medya kenti olduğuna inanmakta, bu topraklara Medya Atropatene denilmesini de buna örnek olarak göstermektedir ${ }^{47}$.

\footnotetext{
${ }^{38}$ Bilgili, 2011, s.219.

${ }^{39}$ Jackson 1906, s.41; Zehtabî (Trz), I, s.266vd.

${ }^{40}$ Buniyatov 1991, s.318.

${ }^{41}$ Zehtabî (Trz), II, s.559vd.

${ }^{42}$ Hamaçî 1370, s.259.

${ }^{43}$ Zehtabî (Trz), II, s.560.

${ }^{44}$ Diakonof 1985, s.86.

${ }^{45}$ Vaux 1900, s.304.

${ }^{46}$ Rawlinson 1841, s.107.

${ }^{47}$ Minorsky 1965, s.83; Taylor 1870, s.116.
} 
Bütün bu bilgilerden, Tebriz kentinin, İskender istilasından ve Perslerin Azerbaycan'da egemenlik kurmuş olduğu dönemlerden çok daha önceleri kurulduğu anlaşılmaktadır ${ }^{48}$. Tebriz şehrinin kuruluşu ile ilgili bazı tarihçiler, şehrin MÖ 4. yüzyılda Büyük İskender'in komutanlarından Atropates tarafından kurulduğuna inanmaktadırlar. Atropates, İskender' in Azerbaycanlı komutanıydı ve aslen İranlıydr ${ }^{49}$. Bu dönemde Azerbaycan topraklarına Yunan ve Roma kaynakları Atropaten adını vermekteydiler ${ }^{50}$. Bunun sebebi bölgenin adının Adurbadegan olmasından ileri gelmektedir. Bilindiği gibi, İskender istilasına karşı en çok direnen Azerbaycan toprakları olmuştur. İskender MÖ. 331 yılında Pers hükümdarı Dara ile yapmış olduğu Gaugamela savaşından zaferle çıkıp bölgeyi ele geçirdikten sonra burasını Atropaten'in sevilen idarecilerinden Atropates'in idaresine vermiştir ${ }^{51}$. Bu komutanın isminin Atropates şeklinde telaffuzu Yunan kaynaklarındaki telaffuzdan dolayıdır. Bu isim Farsçada ise Adurbad $^{52}$ şeklinde geçmekte ve ateşin koruduğu kimse veya ateşin bekçisi anlamlarına gelmektedir ${ }^{53}$.

Bununla beraber Azerbaycan'ın geneli için kullanılan Adurbadegan sözcügü idari amaçla kullanılan bir isim olmakla beraber özelde bir milletin adı değildir. Ateş'in koruduğu ülke anlamına gelen Adurbadegan sözcügünden dolayı Adurbad veya batılıların telaffuzuyla Atropat'ın daha çok bir lakabı anımsattığı görülmektedir. Atropates kendi adını bu topraklara vermediği gibi, buraya vali olduktan sonra bölgenin isminden dolayı Atropates lakabını kazanmıştır. Atropates kendi adını, Azerbaycan ülkesinin adındaki anlamdan dolayı lakap olarak almış olması daha güçlü bir ihtimaldir ${ }^{54}$.

Batılıların Atropaten şeklinde telaffuz ettikleri Adurbadegan sözcügünü Sâsânîler Azerbazegan şeklinde telaffuz etmekteydiler ve bu telaffuz günümüze Azerbaycan olarak gelmiştir. Adurbadegan adı verilen topraklar Tebriz merkezli Güney Azerbaycan topraklarıdır ${ }^{55}$. Kuzey Azerbaycan toprakları için ise o

\footnotetext{
${ }^{48}$ Minorsky vd. 2007, s.487.

${ }^{49}$ Mignan 1834, s.577; Barthold 1975, s.77.

${ }^{50}$ Smith 1883 , s.143.

${ }^{51}$ Buniyatov 1991, s.318; Bosworth ve Baynham 2000, s.300; Arrowsmith 1839, s.599.

52 Leeuw 2000, s.204; Azerbaycan, Yunanca'da Atropaten, Asurca'da Adarbigan, Bizans kaynaklarında Aderbaygan, Ermeni kaynaklarında Atrpatkan, Gürcü dilinde ise Adarbadagani şeklinde geçmektedir. Konuyla ilgili farklı bilgiler için bkz. Doğan 1992, s.8.

${ }^{53}$ Akiner 1983, s.105; Schippmann 1989, s.22; Azerbaycan toprakları üzerinde kurulan ilk krallık bu değildir. Bu topraklar üzerinde kurulan ilk devlet Manna krallığıdır. MÖ. I. bin yılın başlarında bugünkü Hasanlu başkent olmak üzere kurulan bu devlete, MÖ 800'de Urartular son vermişlerdir. Buniyatov 1991, s.318.

${ }^{54}$ Houtsma 1993, s.134; Leeuw 2000, s.33.

${ }^{55}$ Taylor 1870, s.116; Gurbanov 2007, s.38.
} 
dönemlerde kullanılan tabir Albanya' dır $^{56}$. Sâsânîler kendi dönemlerinde Güney Azerbaycan topraklarını Erran olarak da adlandırmışlardır. Erken Ortaçağlarda Tebriz merkezli Güney Azerbaycan toprakları tamamen Sâsânîlerin elinde bulunmaktaydı. Kuzey Azerbaycan (Albanya) toprakları ise Hazar Türklerinin elinde bulunuyordu ${ }^{57}$. Tebriz merkezli topraklar, II. Hüsrev zamanında Hazar ve Bizanslıların Azerbaycan'a yaptıkları bir saldırı ile 623 yılında Sâsânîlerin elinden kısa bir süreliğine çıkmış fakat bir süre sonra geri alınmıştır ${ }^{58}$.

Güney Azerbaycan bölgesinin merkezi olan Tebriz kenti asıl önemine İskender döneminde kavuşmuştur. Önceki adıyla Gazaka denilen Tebriz şehri bu dönemde Atropaten Krallığının başkenti olmuştur ${ }^{59}$. Tebriz şehri, bu dönemde yeniden imar edilmiştir. İlkçağlarda yaşanan bir depremin ardından veya herhangi bir istila sonucunda yıkılışının ardından tekrar kurulmuş olması güçlü bir ihtimaldir ${ }^{60}$. MS. 5. yüzyılda yaşamış olan Ermeni tarihçi Moses Horenasi, Tebriz şehrini, rüyalar şehri Ekbatana'ya benzeterek bu şehir için ikinci Ekbatana tabirini kullanmıştır ${ }^{61}$.

Tebriz kentinin adından hareketle bu şehrin, MÖ birinci bin yılın ikinci yarısında Saka Türkleri tarafindan kurulmuş olma ihtimali de kuvvetli olarak gözükmektedir. Tebriz merkezli Saka imparatorluğunun başbuğu olan Alper Tunga, MÖ. 624 yılında Pers imparatoru Keyhüsrev tarafindan Tebriz'in batısındaki Urumiye gölü kenarında yakalandıktan sonra ülkesinin başkenti olan Tebriz şehrine getirilmiş ve burada idam edilmiştir ${ }^{62}$. Hatta İranlılar onu idam ettikten sonra başını keserek Tebriz kapılarından birisine gömmüşlerdir. Alper Tunga'nın başının gömülü olduğu bu kapıya Dervazey-i Ser (Baş Kapısı) adı verilmiştir. Alper Tunga'dan sonra bile, bu bölge Saka imparatoriçesi olan Tomris tarafından Pers hükümdarı Dara'ya karşı MÖ. 529 yılında başarılı bir şekilde savunulmuş ve Azerbaycan toprakları elde tutulmuştur.

İran milli dininin kurucusu olan Zerdüşt, Tebrizli olduğu için getirmiş olduğu din Atropaten bölgesinde yaygınlaşmış ve Tebriz, Zerdüştlüğün merkezi haline gelmiştir ${ }^{63}$. Sâsânî imparatorluğu dönemindeki ateş tapınaklarının tamamına yakını Azerbaycan bölgesinde bulunmakla beraber, ana tapınak olan Adhur Gushnasb, Tebriz şehrine ait bir banliyöde bulunmaktayd1 ${ }^{64}$. Ateş

\footnotetext{
${ }^{56}$ Barthold 1963, s.532-533.

${ }^{57}$ Yücel 2002, s.446vd.

${ }^{58}$ Kristensen 1364 hș, s.584.

${ }^{59}$ Minahan 2000, s.20; Arrowsmith 1839, s.599; Mignan 1834, s.577.

${ }^{60}$ Dumper 2007, s.339.

${ }^{61}$ Vaux 1900, s.304.

${ }^{62}$ Öztuna 1977, c.I, s.22; Belhî 1339h, s.48. Daha geniş bilgi için bkz. Belhî 2008.

${ }^{63}$ Boyce vd. 1991, s.69vd; Minorsky 1337h, s.8; Malcolm 1806, s.546.

${ }^{64}$ Ayatolahi 2002, s.103, 129, 131.
} 
tapınaklarının, Azerbaycan toprakları üzerinde çok sayıda olmasının nedenleri arasında bölgede mevcut petrol ve doğal gaz yatakları gösterilmektedir. Ateşin bu bölgenin sembolü haline gelmesinden dolayı bölgede çok sayıda ateş tapınağının kurulduğu ifade edilmektedir ${ }^{65}$. Sâsânî imparatorluğu, Zerdüştlük inancını benimsediği halde ne ilginçtir ki Sâsânî başkenti Medâ'in'de ateş tapınağı bulunmamaktaydı. Medâ'in şehrinde taç giyme töreni düzenleyen Sâsânî hükümdarları hükümdarlıklarını kutsamak amacıyla törenden sonra büyük bir merasimle Tebriz şehrine kadar yürümek zorundaydılar ${ }^{66}$. Bu durum Herakleios'un Tebriz kentini yıkıp, ana tapınağını yaktığı 628 yılına kadar devam etmiştir ${ }^{67}$.

Ermeni tarihçi Vardan'a göre, son Part hükümdarı V. Artaban'ı ortadan kaldıran Sâsânî imparatoru Erdeşîr'den intikam almak isteyen Ermeni kralı Khosro'nun kenti kurmuş olduğunu ve Sâsânîlere karşı bir üs haline getirdiğini iddia etmektedir ${ }^{68}$. Fakat bu tarihçinin dışında bu iddiayı savunan kimse yoktur. $\mathrm{Bu}$ iddiayı ortaya atmasının nedeni ise şehrin adının Ermenice "intikam alan" anlamında "Daivrez" sözcüğünü andırmasıdır". Hâlbuki Khosro, Sâsânîler tarafından yıkılan Eşkânî imparatorluğunun intikamını almak ve onların imparatorluklarını devam ettirmek amacıyla Sâsânîler ile daha iyi mücadele edebilmek için ülkesinin merkezini Tebriz'e taşımış ve burayı askerî bir şehir haline getirmek istemiştir ${ }^{70}$. Bu gelişme, Tebriz'in önemini artırmasına ve gelişmesine etki etmiştir. Ermeniler kendilerini Arşaklıların devamı olarak gördükleri için, Arşak krallığını tekrar diriltmek amacıyla bir süre Sâsânîlere karşı mücadele etmişlerdir ${ }^{71}$. Erdeşîr'in, V. Artaban'1 ortadan kaldırmasıyla bölgedeki Part egemenliği yıkılmış ve Tebriz'in de bulunduğu Azerbaycan toprakları kısa bir zaman içerisinde Sâsânî egemenliği altına girmiştir ${ }^{72}$.

V. Artaban'dan sonra oğlu Artabaz, Ermeni hükümdarı II. Tiridates'in de yardımıyla MS. 230 yılına kadar Tebriz şehrini elinde tutmayı başarmıştır. Alan, Kuşan ve Hun gibi Kafkas kavimlerinin desteğini alan Artabaz, bu kavimlerin de yardımıyla Tebriz'i elinden almak isteyen Erdeşîr'i iki defa mağlup etmiş ve burayı sağlama almak için Tebriz şehrine Doj Tavres adıyla bir kale inşa etmiştir. Burada kendi adına gümüş para bastırarak kendisini

\footnotetext{
${ }^{65}$ Leeuw 2000, s. 17.

${ }^{66}$ Schippmann 1989, s.224; Barthold 1975, s. 77.

${ }^{67}$ Houtsma 1987, s.1033.

${ }^{68}$ Smith 1883, s.144; Minorsky vd. 2007, s.487. Dumper 2007, s.339; Smith 1883, s.144; Minorsky 1965, s.83.

${ }^{69}$ Dumper 2007, s.339; Smith 1883, s.144.

${ }^{70}$ Rawlinson 1841, s.107.

${ }^{71}$ Bkz. Garthwaite 2005, s.22, 65. Ayrica bkz. Benjamin 1891, s.158-170.

${ }^{72}$ Karahan (Trz), s.206; Konukçu 1973, s.71.
} 
Part/Eşkânî hükümdarı olarak ilan eden Artabaz, Azerbaycan bölgesini elinde bulundurarak, Tebriz'i merkez olarak seçmiştir ${ }^{73}$. Ermeni kralı Artabaz, Sâsânî hükümdarı Erdeşîr'e karşı; Alanlar, Kuşanlar ve Hunların bulunduğu Kafkas topluluklarının yanı sıra Bizans'ın da desteğini almış ve bir müddet buradaki Ermeni varlığını devam ettirmiştir. Fakat MS. 237 y1lında Azerbaycan ve Ermenistan üzerine büyük bir sefere çıkan Erdeşîr bütün Azerbaycan topraklarını ele geçirdiği gibi Ermenistan'ı da İran egemenliği altına almıştır ${ }^{74}$.

Ermenistan hükümdarı II Arşak ile Sâsânî hükümdarı I. Şapur arasında meydana gelen savaşta, bu şehir Sâsânî eyalet orduları için bir ordugâh olarak kullanılmıştır ${ }^{75}$. Ermeni generali Vasak, Tebriz'de ordugâh kurmuş olan I. Şapur'a ordusuyla saldırmış ve onu mağlup ederek, Sâsânî komutanı Boykan'1 öldürmüştür ${ }^{76}$. Tebriz kentini ele geçiren Ermeni ordusu, kentin merkezindeki kral sarayını yerle bir ederek burada dikili bulunan Sâsânî hükümdarlarından I. Erdeşir ve I. Şapur'un heykellerini de tahrip etmiştir. Tebriz'i, bu dönemde elde tutan Ermeni Vasak'ın oğlu Muşeg, Sâsânî ordusunu bölgenin doğusuna püskürtmüştür ${ }^{77}$. Sâsânî devletinin kurulduğu dönemde Tebriz şehri, kesin olarak Sâsânîlerin eline geçinceye kadar, Ermeniler ile Sâsânîler arasında birkaç defa böylece el değiştirmiştir ${ }^{78}$.

Tebriz şehri, Sâsânî hükümdarı Nersi döneminde, tekrar Sâsânîlerin elinden çıkmıştır. MS. 298 yılında, Diokletionus'un komutanlarından Galerius'a yenilen Nersi, Kuzey Mezopotamya topraklarının tamamını kaybetmiş ve Tebriz elden çıkmıştır. Romalılar, Tebriz merkezli Adurbadegan topraklarını Ermeni kralı Tiridates'e bırakmışlar ve Tiridates de ülkesinin başkentini, Tebriz şehrine nakletmiştir ${ }^{79}$. II. Şapur döneminde Tebriz şehri yine Ermeni Arşak ve Sâsânîler arasında yapılan bir savaş neticesinde talan edilmekten kurtulamamıştır. Ermenistan üzerindeki egemenliğini kuvvetlendirmek isteyen II. Şapur ordusuyla Azerbaycan toprakları üzerinde ilerleyerek Urumiye gölü civarında Ermeni ve Bizans ordusuyla karşılaşarak çetin bir savaşa tutuşmuştur. Bu savaşta Arşak ile birleşen Kafkas Hunları Sâsânîlere karşı savaşmışlardır ${ }^{80}$. Bizans imparatoru Iulianus'un kızıyla evli olan Ermeni Arşak, Bizans'la kurduğu ittifakla ülkesini Şapur'a karşı savunmuş, fakat bu savaş, Batı

\footnotetext{
${ }^{73}$ Horenatsi 1380; Minorsky 1337, s.5; Reisneya (Trz), s.444-445.

${ }^{74}$ Rawlinson 2005, 177.

${ }^{75}$ Bilgili, 2011, s. 219.

${ }^{76}$ Zehtabî (Trz), II, s.396; Minorsky 1337h, s.9.

${ }^{77}$ Minorsky 1965, s.83.

${ }^{78}$ Reisneya (Trz), s.446.

${ }^{79}$ Taylor 1870, s.441-2; Porter 1822, c.II, s.97; Rawlinson 2005, s.577-578; Malcolm 1806, s.83; Jackson 1906, s.39.

${ }^{80}$ Zehtabî (Trz), II, s.401.
} 
Azerbaycan ve özellikle Tebriz için bir yıkımı beraberinde getirmiştir. Şapur'un, Iulianus ve Ermenilerle yapmış olduğu bu savaşı Tebriz ve diğer birçok yerde kayalara ve saray duvarlarına resmederek kazanmış olduğu zaferleri ölümsüzleştirmek istemiştir.

Sâsânî hükümdarı Kubad döneminde Tebriz şehrinde kendisi de Tebrizli olan Mazdek $^{81}$ ortaya çıkarak kendi inancını Azerbaycan toprakları üzerinde yaymaya başlamıştır ${ }^{82}$. Zamanla Sâsânî hükümdarı Kubad'1 etkisi altına alarak Sâsânî devleti üzerinde söz hakkına sahip olan Mazdek, getirmiş olduğu felsefi akımı, İran toprakları üzerinde geniş bir alana yayabilmiştir ${ }^{83}$. Mazdek'in ortaya çıktığı dönem, MS. 484 yılında Akhunlar tarafından yenilgiye uğrayan Sâsânî hükümdarı Firuz'un ordusuyla birlikte imha edildiği zor bir döneme rastlamaktadır $^{84}$. Bu siyasi boşluğu iyi değerlendiren Mazdek getirmiş olduğu felsefi akımı yayma firsatı bularak, geniş bir halk desteğine ulaşmış ve zamanla Sâsânî sarayını ve hükümdarlarını etkileyecek kadar kuvvetli bir konuma ulaşmıştır. Mazdek'in getirmiş olduğu bu akımın geniş bir alana yayılma sebeplerinden birisi de ortaya koymuş olduğu görüşü, dinsel ağırlıkların merkezi konumunda olan Tebriz şehrinden başlatmış olmasıdır. Tebriz'in hem dinsel özelliği ve hem de din adamlarının hâkim olduğu şehirde fakir halkın, din adamlarının Zerdüştlük adına yapmış oldukları uygulamalardan bıkmış olmaları, bu akıma eğilimi arttırarak Mazdekizm'in tutulmasına ve buradan bütün İran ülkesine yayılmasına neden olmuştur ${ }^{85}$. Kubad'ın, Mazdek'e verdiği destekten dolayı Sâsânî soyluları tarafindan tahttan indirilmesi üzerine Mazdek, geniş bir halk desteğine sahip olduğu Azerbaycan topraklarına sığınmıştır ${ }^{86}$.

$\mathrm{Bu}$ dönem Sâsânî sarayı, Akhunların etkisi altına girmiş ve ülke ekonomik yönden zayıflamış halk arasında maddi bir eşitsizlik ortaya çıkarak; soylular ve halk arasında ekonomik bir uçurum meydana gelmiştir ${ }^{87}$. Bu dönemdeki sosyal eşitsizliğe karşı mücadele eden Mazdek, sahip olduğu ideolojiyi, Zerdüşt dininin ıslahı şeklinde ortaya koyarak bu dinin bir devamı

\footnotetext{
${ }^{81}$ Sâsânî şahı Kubâd'ın (Kubâd b. Firûz b. Yezdicerd) saltanatı döneminde ortaya çıkan Mazdek, MS. 478-531 yılları arasında yaşamıştır. Köylü sınıfının içerisinden çıkan ve özgürlükçülügü esas alan Mazdek, toplumsal eşitliği savunan bir ideoloji ortaya koymuştur. Bkz. Niray 2001, s.17. Altungök 2006, s.89. Bu konuda daha detaylı bilgi için Bkz. İbnu'l-Esîr (Trz.), s.413-414; İbnu'l-Belhî 2008, s.78, 81-83; Kister 2008, s.25; Grousset 2006, s.223; Chokr 2002, s.58-59; ez-Zâbit 1984, s.245.

${ }^{82}$ Marşak 2002, s.170-177.

${ }^{83}$ Kristensen 1368h, s.364; Zehtabî (Trz), II, s.417.

${ }^{84}$ Büchner 1965, s.245.

${ }^{85}$ Marşak 2002, s.172; Altungök 2006, s. 12.

${ }^{86}$ İbnu'l-Belhi 1339h, s.86.

${ }^{87}$ Baratova 2002, s.90.
} 
gibi hareket etmiştii ${ }^{88}$. İran milli dini Zerdüştlük üzerinde tahribat yaptığı ve insanları saptırdığ 1 gerekçesiyle Sâsânîlerin en kudretli şahı olan I. Hüsrev Enûşirvân tarafından ortadan kaldırılmıştır ${ }^{89}$.

Kubad, Hazar Türklerinin güneye doğru inerek Güney Azerbaycan bölgesini ele geçirme çabalarına karşı, Hazarlarla uzun süren savaşlara girmiştir $^{90}$. Hazarların Güney Azerbaycan'1 ele geçirme çabalarına karşı Enuşirvan, Babu'l-Ebvab ${ }^{91}$ adı verilen Derbend ve Daryal kapılarını yaptırarak Hazar akınlarını durdurmaya çalışmış ve barış yoluyla 10.000 civarında Hazar Türkünü, Tebriz ve Adurbadegan topraklarına yerleştirmiştir.

Tebriz ve civar kasabaları, Sâsânî kralı IV. Hürmüz döneminde şiddetli bir taht kavgasına sahne olmuştur. Sâsânî ileri gelenleri, IV. Hürmüz'ü devirerek yerine oğlu II. Hüsrev'i getirmek istediler. Batı Göktürk İmparatoru İstemi Kağan'ın Sâsânî hükümdarı Enuşirvan ile evli olan kızı Fakim'in oğlu IV. Hürmüz, İran soylularına karşı dihkanlar ${ }^{92}$ (toprak ağaları, derebeyleri) ve fakir halkın yanında yer alınca, bozorgan ${ }^{93}$ adı verilen Sâsânî soylularının tepkilerine hedef oldu. On dört yıllık saltanatının sonlarına doğru kendisinden bıkan Sâsânî soylularının komplosundan haberdar olan IV. Hürmüz, II. Hüsrev’i tutuklatmak istedi. Bir rivayete göre, II. Hüsrev Azerbaycan'a kaçarak Tebriz merzuban'ına ${ }^{94}$ sığındı. Nitekim İbnu'l-Belhî, Hüsrev'in Azerbaycan'daki akrabalarına sığındığını anlatarak dayıları hakkında bilgi vermektedir ${ }^{95}$. IV. Hürmüz'ün Sâsânî ileri gelenleri tarafindan tutuklanarak hapse atılması üzerine, II. Hüsrev, Azerbaycan valisinin yardımıyla gelerek tahta oturmuştur.

\footnotetext{
${ }^{88}$ Has 2004, s.523.

${ }^{89}$ Nefisi 1331h, s.67; İbnu'l-Belhî 1339h, s.90. Daha geniş bilgi için bkz. İbnu'l-Belhî 2008.

${ }^{90}$ Altungök 2006, s.63.

91 Babu'l-Ebvab (Derbend): Hazar Denizi'nin kıyısında deniz ile kara arasında 3-4 km uzunluğunda Derbent şehrinde mevcut olan bir geçittir. Kuzey kavimlerinin istilasını önlemek amacıyla kurulmuş olan bu şehir askeri, ticari ve zirai açıdan önemli bir konuma sahipti. Bkz. Barthold 1963, s.532-533; Bu kapının kuzeyinde kalan topraklarda Türkler meskûn olduğu için Derbend'e Türk Kapısı adı da verilmiştir. Bkz. Gömeç 1999, s.5.

92 Riza 1376h, s.126; Büchner 1966, s.246. Sâsânîler döneminde genelde köylerin ve bu köylere bağlı tarım arazilerinin yönetiminden sorumlu olan dihkanlar, denetimleri altındaki topraklarda dirlik ve düzenin teminatı olarak hareket ederler ve devletin kolayca vergi toplamasına yardımcı olurlardı. Bkz. Sümer 1991, s.289.

${ }^{93}$ Bozorgan: Sâsânî toplumu içerisinde din adamları, askerler ve diğer soyluların hepsine verilen addır. Bozorgan sözcük anlamı olarak büyükler anlamına gelmektedir ve bu kavram Sâsânî toplumundaki bütün asilzadeleri ifade etmek için kullanılırdı. Bkz. Nicolle 1996, s.10.

94 Altungök 2006, s.66; Meşkür 1366h, s.97; "Merz" (sınır) ile "ban" (bekçi) sözcüklerinin birleşmesiyle oluşan "merzuban" sınır bekçisi, sınır muhafizı anlamlarına gelmekteydi. Genelde sınır bölgesindeki eyaletlerin komutanlarına verilen bir isim idi. Bkz. Yazıcı 2004, s.255; Rıza 1376h, s.14; Nicolle 1996, s.14; Behnam, 1337h, s.186.

95 İbnu'l-Belhî 1339h, s.100vd. Daha geniş bilgi için bkz, İbnu'l-Belhî, 2008.
} 
Tebriz şehrinin içerisinde bulunduğu Güney Azerbaycan toprakları, MS. 589 yılında Sâsânî ordu komutanı Behram Çubin ile II. Hüsrev arasında cereyan eden şiddetli bir savaşa sahne oldu. IV. Hürmüz ile zitlaşan Behram başkaldırarak Doğu Azerbaycan'da ayaklanma başlattı. Bu zıtlaşmayı firsat bilen Sâsânî soylularının Hürmüz'ü tutuklayarak ortadan kaldırmalarından sonra, Bizans'ın da desteğini alan II. Hüsrev, Behram'1 yenerek babasının tahtını geri aldı, ancak bu savaşların merkezi durumunda olan Doğu Azerbaycan toprakları ve Tebriz, çevresi ile beraber yıkımdan kurtulamadı. Behram ise II. Hüsrev'den kaçarak Tebriz'e çekildi. Bizans İmparatoru Mavrikios'un da desteği ile Narses komutasındaki Bizans ve Sâsânî ordusu, Doğu Azerbaycan'a çekilen Behram Çubin'i mağlub etti. Behram bu olaydan sonra kaçarak Göktürklere sığındıysa da, burada bir suikast sonucu öldürüldü ${ }^{96}$.

MS. 624 yılında Bizans imparatoru Herakleios, önce Ermenistan'a, buradan aldığ 1 destekle Azerbaycan topraklarına girmiştir ${ }^{97}$. Herakleios, Sâsânî topraklarına girdiğinde, Sâsânî şahı II. Hüsrev, Tebriz şehrinde ordusuyla konaklamış bulunuyordu. Bizans imparatorunun geldiğini haber alan II. Hüsrev, Medâ'in'e doğru geri çekilmeye başladı. Tebriz'e ordusuyla giren Herakleios şehirdeki saray, tapınak, devlet kurumları gibi önemli mimari eserleri yerle bir etmiştir. Bizanslılar, Sâsânîlerin daha önce Kudüs'te yapmış oldukları kıyıma misilleme olarak, Sâsânîlerin kutsal başkenti olan Tebriz ve civarını yakıp yıkarak büyük bir katliam yapmışlar ve Hz. İsa'nın doğduğu Doğuş Kilisesi'ne karşılık da, Adhur Gushnasb'ı yerle bir etmişlerdir. Bizans hükümdarı Herakleios, daha önce Hz. İsa'nın kutsal haçını İran'a getiren II. Hüsrev'in elinden bu haçı alarak tekrar ülkesine geri götürmüştür ${ }^{98}$. Bu esnada Tebriz'de sert bir hava muhalefetiyle karşılaşan Herakleios, yönünü kuzeye doğru çevirmek zorunda kalmıştır. Ermenistan'a doğru yönelen Herakleios, Tebriz halkından sekiz bin civarında savaşçıyı da esir olarak yanında götürdü. Fakat sert hava koşulları nedeniyle bu kadar esiri götüremeyeceğini anlayan bu hükümdar, esirleri Ermenistan'a varmadan serbest birakmak zorunda kald1 ${ }^{99}$.

Herakleios ile başa çıkamayacağını anlayınca, Medâ'in'e geri dönmek zorunda kalan Sâsânî hükümdarı II. Hüsrev, oğlu Şireveyh tarafından bir suikast sonucunda öldürülmüştür. Sâsânî tahtının el değiştirmesinden sonra, Şireveyh ile Herakleios arasında Tebriz'de bir barış anlaşması imzalanmıştır. Hava muhalefetinden dolayı kuzeye yönelmiş olan Herakleios, havaların düzelmesi ile tekrar güneye inmiş ve Tebriz şehrine vardığında, Şireveyh'in tahta çıkışını

\footnotetext{
${ }^{96}$ İbnu'l-Belhî 1339h, s.102; Reisneya (Trz), s.456-457; Garthwaite 2005, s.109.

${ }^{97}$ Garthwaite 2005, s.110.

${ }^{98}$ Reisneya (Trz), s.488-490: Furon 1943, s.100.

${ }^{99}$ Reisneya (Trz), s.494: Greatrex ve Lieu 2002, II, s.200vd.
} 
ve II. Hüsrev'in öldürüldüğünü haber veren ulaklarına rastlamıştır. Bu gelişmeleri duyan Herakleios Tebriz'de ordusunu konaklatmış ve Şireveyh ile barış anlaşması imzalayarak Azerbaycan topraklarını terk etmiştir ${ }^{100}$.

Herakleios'un gerçekleştirmiş olduğu yıkımlardan sonra Tebriz kenti bir köy haline gelmiştir. Daha çok askeri amaçlarla kullanılan bu şehir, Sâsânî devletinin askeri gücünü kaybetmesiyle birlikte eski önemini yitirmiştir. Bu esnada Sâsânî ordusunun büyük bir çoğunluğu, doğuda Göktürklerle yapılan savaşlarla meşgul olmakta, geri kalanları ise Herakleios öncülüğündeki Bizans ve Hazar orduları karşısında çözülmüş durumdaydılar. Göktürk hükümdarı Tong Yabgu, ordularıla İsfahan önlerine kadar gelmiş bulunmaktayd $1^{101}$. Sâsânî askeri varlığının çözülmesi, Tebriz şehrinin önemini yitirmesine sebep olmuştur. Öyle ki, MS 642 yılında İslam fetihleri döneminde bu şehir, Sâsânî merzubanı tarafından savunma amaçlı kullanılamayacak kadar küçük bir kasaba halindeydi ${ }^{102}$. İslam fetihlerinden önce burası Ferruh Hürmüz adında Sâsânî soylularından birisine bağlıydı. Bu merzuban, Herakleios'un Sâsânîlerle yapmış olduğu barış anlaşmasından sonra, Azerbaycan bölgesini boşaltmasıyla beraber bölgenin merzubanı olmuştur. Anılan idareci, Araplara karşı savaşan İran ordusunun komutanı Rüstem'in babasıdı1 ${ }^{103}$. Bu merzuban, Erdebil şehrinde ikamet etmekteydi ve bu dönemde bir kasaba halinde olan Tebriz de buraya bağlanmışt1 ${ }^{104}$. İslam fetihleri sırasında Tebriz MS. 644 y1lında bir depremle yıkılarak eski canlılığını yitirmesinden dolayı, Azerbaycan bölgesinin merkezi Erdebil'e kaymıştı. Bu nedenle, Arap orduları Azerbaycan topraklarını ele geçirmek için Erdebil şehrine yönelmişler ve buray1 ele geçirmişlerdir ${ }^{105}$. Azerbaycan topraklarını ele geçirdikten sonra buraya ilk atanan Müslüman vali Huzeyfetü'l-Yeman olmuş ve Erdebil şehrinde ikamet etmiştir ${ }^{106}$. Müslümanların, Sâsânîler ve Hazarlar ile olan savaşlarında Tebriz adına hiç rastlanmaz. Sadece Minorsky, Tebriz kentine ait Urumiye gölü etrafındaki bazı kalelerin Hz. Ömer'in komutanlarından Utbe bin Farkad tarafindan ele geçirildiğini bildirmektedir ${ }^{107}$. Sâsânî devletinin Hz. Ömer döneminde y1kılmasından sonra, yine halifenin emriyle Utbe b Gazvan'ın Basra kentinin temellerini atmasından sonra Tebriz şehri; Bahreyn, Umman, Mekran, Kirman, Fars, Huzistan gibi diğer şehir ve bölgelerle beraber, Mah-1 Basra olarak

\footnotetext{
${ }^{100}$ Reisneya (Trz), s.494; Jonston 2006, s.85. Şireveyh hakkında geniş bilgi için bkz. Hattab 1998, s. 78.

101 Grenard 1992, s.21; Sinor 2002, s.414.

${ }^{102}$ Reisneya (Trz), s.458; Kristensen 1368h, s.649vd.

${ }^{103}$ Kristensen 1368 h, s. 458

${ }^{104}$ Christensen 1993, s.208.

${ }^{105}$ Minorsky $1337 \mathrm{~h}$, s.9.

${ }^{106}$ Barthold 1308h, s.286.

${ }^{107}$ Houtsma 1987, s.1033.
} 
anılmaya başlamış ve idari açıdan Basra'ya bağlı bir yerleşim yeri halini almıştır ${ }^{108}$.

Tebriz'in Müslümanlarca ele geçirilmesinden önce, Herakleios'un şehri yıkmasından itibaren, Abbasî halifesi Hârûnu'r-Reşîd'in hanımı Zübeyde ${ }^{109}$ tarafından tekrar imar edilinceye kadar küçük bir köy şeklinde kaldığ 1 söylenmektedir ${ }^{110}$. VIII. yüzyılın sonlarına doğru Zübeyde tarafindan gerçekleştirilen bu imar faaliyeti ile beraber, Tebriz şehri yeni ve bugünkü görünümüne kavuşmuştur. Zübeyde tarafindan tekrar imar edilen şehir, ancak Abbasî halifesi Mütevekkil zamanında asıl görkemine kavuşmuştur. Mütevekkil döneminde küçük bir şehir halinde olan Tebriz, bu dönemde bayındır hale getirilerek burası ülkenin farklı yerlerinden getirilen nüfusla beslenmiştir ${ }^{111}$. Abbasiler döneminde Tebriz şehrini ziyaret eden Yakut, şehrin önemli bir sanat merkezi olduğunu ve bu şehirde dokunan kumaşların bütün ülkelere ihraç edildiğini bildirmektedir ${ }^{112}$. Abbasilerden sonra Tebriz, Moğol istilasına kadar yerli atabekler tarafından yönetilmiş̧ir.

Arapların Sâsânî devletini yıkmalarından sonra bazı Arap kabileleri, Azerbaycan şehirlerine yerleşmeye başlamıştır. Abbasî halifesi Ebu Cafer elMansûr, Yezîd b. Hâtim'i, Azerbaycan valisi tayin edince, anılan vali Basra'daki birçok Yemen kökenli kabile mensubunu Karacadağ, Urumiye ve Tebriz şehrine yerleştirerek, burada toprak ve ev edinmelerini sağladı. Bu iskân faaliyetinden sonra Tebriz şehrinin demografik yapısında ciddi bir anlamda kırılma olmuş, şehir, Arap çoğunluklu bir yer haline gelmiştir. Arapların özellikle bu şehirleri tercih etmelerinin sebebi, Tebriz'in doğal güzelliğinden ve zenginliğinden kaynaklanıyordu. el-Mukaddesî, bu dönemde Tebriz ve Mugan şehirlerinin Azerbaycan topraklarının iki nadide incisi olduğunu belirtmekte, Tebriz'in birçok sulama kanalına sahip, etrafı bağ ve bahçelerle dolu yemyeşil bir şehir olduğunu da ifade etmektedir ${ }^{113}$.

Abbasiler döneminde Tebriz ve civarı, Zerdüştlüğü yeniden canlandırmak isteyen Babek ayaklanmasına sahne olmuştur. Abbasiler'i oldukça zorlayan bu ayaklanma, bütün Azerbaycan topraklarını etkisi altına almıştır ${ }^{114}$. Bu dönemde

\footnotetext{
${ }^{108}$ İbnu'l-Belhî 1339h, s.120; Şukri Faysal (Trz.), s.203-207.

${ }^{109}$ Zübayda: (762-831) Zübeyde bint-i Cafer, Abbasi halifesi Hârûn'un eşi ve Hârûn'un halefi olan oğlu Emin'in annesidir. MS. 781'de Hârûn ile evlenen Zübeyde'nin asıl adı Anat al-Aziz idi. Halife Mansur, bu cariyeye, "karagöz çiçeği" anlamına gelen "zubda" yı çağrıştıran fakat "tereyağı" anlamına gelen Zubayda adını vermiștir. Zettersteen 1986, s.634; Elgood 2010, s.311.

${ }^{110}$ Minorsky 1965, s.84; Dumper 2007, s.339.

${ }^{111}$ Strange 2011, s.161.

${ }^{112}$ Christensen 1993, s.211; Barthold 1975, s.79.

${ }^{113}$ Togan 1970, s.95; Strange 2011, s.161.

${ }^{114}$ Yildız 1991, s.376vd.
} 
Tebriz, sağlam ve büyük bir kaleye sahipti. Bölge, Abbasî halifesi elMütevekkil döneminde, onun hizmetinde bulunan ve Sâc oğulları beyliğinin kurucusu olan Ebu's-Sâc Divdad'ın idaresine bırakılmış ve Sac Oğulları Beyliği, MS. 885-930 yılları arasında Azerbaycan'ın diğer bölgelerine hâkim olmuşlardır $^{115}$. MS. 960'lı yıllarda ise, Abbasiler'e bağlı Revvadi ${ }^{116}$ ailesinin elinde olan Tebriz, Abbasilerin siyasi otoritelerini yitirmesi ve Revvadilerin içine düşmüş olduğu karışıklıklardan dolayı bölgeyle birlikte önemini yitirmeye başlamıştır. Bundan dolayı, Tebriz, eski siyasi ve ticari canlılığını kaybetmiş ve halkının büyük bir kısmı başka yerlere göç ettiğinden, burası küçük bir köy haline gelmiştir ${ }^{117}$. Bu dönemde Tebriz, Vahsudan el-Ravadî'nin hâkimiyeti altında bulunuyordu ${ }^{118}$. Tebriz şehrinin bütünüyle bir Türk şehri haline gelmesi bu dönemlerdeki Oğuz akınlarından sonra gerçekleşmiş, bu gelişmenin doğal bir sonucu olarak da bugünkü Azeri nüfusu ortaya çıkmıştır ${ }^{119}$.

\section{Tebriz'de Tabiî Âfetler}

Tebriz Erken Ortaçağlarda Bizans ve Ermeni kralları tarafından yıkıma uğratıldığ1 gibi, depremlerle de büyük bir yıkıma uğramıştır. Şehrin sahip olduğu antik tarihi miras, ya depremlerle ya da istilalarla birçok defa ortadan kalkmıştır ${ }^{120}$. Bunun sonucunda da taşımış olduğu tarihi miras günümüze kadar ulaşamamıştır. Tebriz'in ilk tespit edilen depremi, MS. 644 y1lında İslam fetihleri sırasında meydana gelmiştir ${ }^{121}$. Altı şiddetindeki bu deprem, şehri haritadan silecek kadar büyük bir yıkıma sebep olmuştur. Buranın yaşamış olduğu ikinci büyük yıkıcı deprem ise MS. 694 yılında gerçekleşmiştir. Bu sırada Tebriz, küçük bir yerleşim yeri olduğu için depremin yıkıcı etkisi öncekine göre daha az olmuştur.

İbn Hurdazbih, kitabını yazdığı dönemlerde, Tebriz'in büyük bir depremle yıkıldığını, fakat daha sonra, Mütevekkil döneminde şehrin tekrar bina edildiğini yazmaktadır ${ }^{122}$. Mütevekkil döneminde MS. 858 y1lında

\footnotetext{
${ }^{115}$ Minorsky 1965, s.83.

${ }^{116}$ Revvadîler: Yemen'in Himyer bölgesinden kopma Ezd kabilesi mensubu Arapların bir kolunu teşkil etmekle beraber Irak, Suriye ve İran topraklarının fethi sırasında kuzeye doğru gitmiş ve eski Atropaten topraklarını mesken tutarak buralarda yurt edinmiş ve zamanla Kürtleşmişlerdir. Egemenlikleri, MS. 960-1055 yılları arasını kapsamaktadır. Bosworth 1968, s.32, 33; İbnu'1Haldun 1996, s.622.

${ }^{117}$ İbnu'l-Havkal 1338h, s.85; Barthold 1975, s.79; Dumper 2007, s.339.

${ }^{118}$ Madelung 1975, s.233; Bosworth 1968, s.32.

${ }^{119}$ Naroditskaya 2002, s.6; Turan 1965, s.214-216.

${ }^{120}$ Smith 1883 , s. 144.

${ }^{121}$ Melville 1981, s.160.

${ }^{122}$ Minorsky 1337h, s.10.
} 
gerçekleşen bu depremin yıkıcı etkilerinden ve Tebriz üzerinde bıraktığ1 olumsuzluklardan Hamdullah Müstevfi de geniş bir şekilde bahsetmiştir ${ }^{123}$. Bu deprem sırasında Tebriz büyük bir şehir olduğu için yıkımın etkisi, MS. 644 y1lındaki depremin etkisi gibi çok büyük olmuştur. Fakat şehir ekonomik ve ticari öneminden dolayı Mütevekkil tarafından tekrar inşa edilmiştir. Bu deprem, Zübeyde'nin, Tebriz kentini MS. 791 yılında imar etmesinden 67 yıl sonrasına rastlamaktadir ${ }^{124}$. Anlatılanlara göre, deprem yedi gün boyunca devam etmiş ve yedinci günün sonunda şehir dümdüz bir hale gelmiştir. Tebriz'in yaşamış olduğu üçüncü büyük felaket ise MS. 1070 yılında meydana gelmiştir ${ }^{125}$. Doğu Azerbaycan'ın birçok ilini yerle bir eden 7,5 şiddetindeki bu deprem, Tebriz'i tamamen ortadan kaldırmıştır. Selçuklular dönemine rastlayan bu deprem sirasinda Tebriz, Vahsudan el-Revvadi'nin hâkimiyeti altında bulunuyordu ve kaydedilenlere göre, deprem esnasında kırk binden fazla insan ölmüştü ${ }^{126}$. Abdülvehap Tarzi, Nasır-1 Hüsrev'in, Sefername adlı seyahatnamesine yazmış olduğu dipnotlardan birinde, anılan deprem hakkında şu satırlara yer verir: "Bütün Şark tarihçileri, Hicrî 434'de Tebriz'in büyük bir kısmını yıkan korkunç depremi kaydederler". Süyûtî, "Keşfu's-Salsale fi Evsâfi'z-Zelzele"sinde, İbnu'l-Kesîr ve Zehebî'nin kayıtlarına dayanarak bu felaket hakkında kısaca malûmat vermektedir. İbnu'l-Esîr, bu vakayı şöyle anlatıyor; "(h.) 434 yllında şiddetli bir deprem, Tebriz şehrini yerinden oynattl. Kale, surlar, evler, çarşılar ve hükümet sarayının büyük kısmı hep hâk ile yeksan oldu. O esnada bir bahçede bulunan emir Ebu Mansûr Vehsûdan, ölümden kurtuldu. Ölenlerin, sayımdan sonra 50 bin kişiye vardiğı anlaşıldl. Emîr bu müthiş faciadan duyduğu teessürü belirtmek üzere siyahlar giyindi”". Yâfiî ve Zehebî, meşhur fikıh bilgini Ebu Zer Abbâd el-Herevî'nin kendi evinin enkazı altında kalarak öldüğünü yazıyor. Öldüğünde yetmiş sekiz yaşındaydı. Kadı Rükneddin, bu depremin Müneccim Ebu Tâhir-i Şirâzî tarafından haber verilmiş olduğunu bildiriyor. Emîr Mansûr, bu âlimin tavsiyesi üzerine (h.) 435'de güneş akrep burcuna girdiği anda, şehrin tekrar kurulmasına başlamıştı. Şehrin geçirdiği bu müthiş sarsıntıyı şair Tebrizli Katran, bir mersiye ile tasvir etmiştir ${ }^{127}$.

Bunun dışında MS. 858 ve MS. 1070 yılları arasındaki bu iki büyük deprem arasında sırasıyla 868, 949, 1020 ve 1042 yıllarında da şiddetli depremler meydana gelmiş fakat fazla bir yıkım olmamıştır ${ }^{128}$. Hamdullah

\footnotetext{
${ }^{123}$ Strange 2011, s. 162.

${ }^{124}$ Melville 1981, s.159.

${ }^{125}$ Strange 2011, s.162; Madelung 1975, s.239.

${ }^{126}$ Christensen 1993, s.211; Wilson 1930, s.104; Madelung 1975, s.233.

${ }^{127}$ Nasır-1 Hüsrev 1950, s.171-172.

${ }^{128}$ Ambraseys 1982, s.5, 8, 9, 11vd; Melville 1981, s.159.
} 
Kazvinî, bu son yıkımdan sonra insanların, şehrin artık böyle büyük bir depreme uğramayacağına inanarak şehri tekrar aynı noktada inşa ettiklerini ifade etmektedir. Gerçekten de anılan depremden sonra müellifin kendi zamanına kadar şehirde üç yüz yıl boyunca deprem olmadığı da ifade edilmektedir ${ }^{129}$. Verilen bilgilerden de anlaşıldı $\breve{g}_{1}$ gibi, Ortaçağ boyunca meydana gelen depremler sonucunda Tebriz defalarca yıkılmış ve yeniden inşa edilmiştir. Müstevfi, şehrin yedi komşu bölgeden oluştuğunu belirtmekle beraber, bunun sebebi olarak depremlerle y1kılmasından sonra tekrar farklı noktalarda kurulmasından kaynaklandığı sonucuna varmaktadır ${ }^{130}$.

\section{Tebriz'in Ekonomik Özellikleri}

Erken Ortaçağlarda ipek yolu üzerinde önemli bir konuma sahip olan Tebriz kenti, doğu ve batının buluşma noktasında önemli bir pazar kenti halini almış ve bu konumundan dolayı dervazey-i maşrık zemin (doğu ülkesinin kapıs1) adıyla anılmaya başlanmıştır. Bölgenin önemli ticaret ve endüstri merkezi olma özelliğine sahip olan Tebriz kenti, dokuma sanayi ve özellikle "halıları" ile meşhurdu ve Sâsânîler döneminde Azerbaycan eyaletinin önemli bir halıcılık dokuma merkezi konumundayd ${ }^{131}$. Dokumacılığın yanında inşaat sanayisine de sahip olan şehir; tarım aletleri ve ev eşyası üretiminde de önemli bir yere sahipti. İbnu'l-Havkal, Tebriz kentinin Azerbaycan'in en aktif ticaret merkezi olduğunu, ayrıca buradaki dokuma ve kumaş endüstrisinin de bir o kadar ilerleme kaydettiğini, hatta Ermeni kumaşlarının bile bu şehirde dokunduğunu dile getirmektedir ${ }^{132}$. Ayrıca Tebriz şehrinde altın sırma ile işlenmiş ipeklerden başka daha pek çok türde ipekli kumaşlar imal ediliyordu ve bu kumaşlar yüksek fiyatlarda alıcı bulmaktaydı. İpekli dokumanın yanında kadife üretimi de yaygın bir yere sahipti. Bunun yanında, burada Attabî, Saklaton, Hatâî ve Atlas kumaşlar dokunuyor, bunların büyük bir kısmı doğu ve batı ülkelerine ihraç ediliyordu. Tebriz'de dokunan tekstil ürünlerinin, Çin'in en uzak noktalarına kadar gönderildiği rivayet edilmektedir ${ }^{133}$.

Sâsânîler döneminde, aralarında Tebriz'in de bulunduğu Azerbaycan şehirlerinin vergileri, Azerbazegan Amargar adı verilen vergi memurları tarafından toplanmaktaydı. Bu görevli özellikle Azerbaycan toprakları için görevlendirilmiş yüksek rütbeli bir devlet memuruydu ${ }^{134}$. Tebriz şehri, anılan

\footnotetext{
129 Barthold 1975, s.82.

${ }^{130}$ Strange 2011, s. 162.

131 Zehtabî (Trz), II, s.606.

132 İbnu'l-Havkal 1338h, s.93.

133 Rossabi 2010, s.104. Bak1r 2005, s.157; Strange 2011, s.161.

134 Zehtabî (Trz), II, s.397; Altungök 2006, s.83.
} 
özelliklerinden dolayı ve sahip olduğu ekonomik yapısı itibariyle Sâsânî devletine önemli bir gelir bırakmaktaydı.

Tebriz, Ermeniler için de önemli bir ticaret merkeziydi. Onlar, ihtiyaç duydukları ticari malları, malzemeleri, binek hayvanlarını, koyunları, kumaşları, Selmas yapımına benzeyen ve fiyatı bir dinar ile on dinar arasında değişen güzel Ermeni kemerlerini, Tebriz kentinden satın alıyorlardı. Bu esnada benzersiz dokunmuş Ermeni minderleri, sebaniye, makrama ve mendiller Tebriz'den temin edilirdi ${ }^{135}$.

İspanyol elçisi Ruy Gonzales de Clavijo, Tebriz çarşılarında başta dokuma ürünleri olmak üzere satılan eşyalarla ilgili olarak şunları nakletmiştir: "Şehirde pek çok güzel yapı ve ev ile karşılaştık. Şehrin kapıları meydanlara açıllyor ve bu meydanların her biri bir kervansaray teşkil ediyor. Kervansarayların içinde ayrl ayrl daireler ve mağazalar vardır. Kervansaraylardan çıkınca çarşılara varılır. Bu çarşılarda her çeşit mal satılır. Ipekliler, pamuklular, yünlüler, krepler, taftalar, mücevherât ve başka türlü türlü şeyler bulunuyor ${ }^{136}$."

Tebriz, tarih boyunca doğu ve batı arasında önemli bir güzergâh üzerinde bulunmaktayd ${ }^{137}$. Buna rağmen Minorsky, Anadolu üzerinden gelen ticaret yolunun Amid, Van, Meraga, Erdebil üzerinden güneye doğru kıvrıldığını ve Tebriz'i içermediğini söyler. Bu durum, Tebriz'in güney-kuzey ticaret yolu üzerinde olmasından kaynaklanmaktaydı. Kafkas kavimleri arasında siyasi birlik olmadığı için bölgenin karışık olmasından dolayı bu ticaret yolunun emniyetli olmaması nedeniyle Tebriz şehri güzergâh olarak pek tercih edilmemekteydi ${ }^{138}$. Buna ek olarak Hamdullah Kazvinî, Karabağ üzerinden Aher yolu ile güneybatıya Tebriz üzerinden inen bir yoldan bahsetmiştir. Ayrıca Sâsânîler döneminde Tebriz ve Ninova'yı birbirine bağlayan önemli bir yol daha inşa edilmişti ${ }^{139}$. Kuzey-güney istikametinde kilit bir noktada olması sebebiyle Tebriz şehri ve civarı Azerbaycan bölgesi için hayati bir öneme haiz bulunmaktaydi.

Sâsânîler döneminin ortalarından itibaren uzak doğudan gelerek Rey ve Zencan üzerinden Doğu Anadolu, Kafkaslar ve Karadeniz'e açılan Orta İpek Yolu, bu yolda olan Tebriz üzerinden geçerek farklı yönlere ayrılmaktayd ${ }^{140}$. Bu güzergâh üzerinden Bizans'a ve batı ülkelerine, ham ipek, ipek ürünleri,

\footnotetext{
${ }^{135}$ Dumper 2007, s.339; İbnu'l-Havkal 1338h, s.92.

${ }^{136}$ Clavijo 1993, s.97.

${ }^{137}$ Rossabi 2010, s.98.

${ }^{138}$ Houtsma 1987, s.1033

${ }^{139}$ Rawlinson 1841, s.43.

${ }^{140}$ Reisneya (Trz), s.658.
} 
mücevher, baharat, 1tırlı maddeler, kürk, harem köleleri, vahşi hayvanlar, kıymetli taşlar, mutfak eşyaları, nadir bulunan sanatsal ürünler gibi değerli eşyaların ihracatı yapılmaktaydı ${ }^{141}$. Sâsânîler, kuzey-güney istikametindeki bütün ticari yollar İranlıların elinde bulunuyor, Kafkas dağlarından geçen ticari yolları, Hazar ve Alan kapılarını, Daryal kapısını, kuzeyli göçebe akınlarına karşı koruyorlard1 ${ }^{142}$.

Ayrıca Sâsânî ülkesinin önemli miktarda gümüş ihtiyacı, gümüş yatakları bulunan Tebriz şehrinden karşılanmaktayd ${ }^{143}$. Buradan çıkarılan gümüş madeni Sâsânî sikkesi olan dirhemlerin yapımı için darphanelere ve mutfak eşyası üretmek amaciyla endüstriyel şehirlere gönderilirdi. Tebriz'in Karabağ ve Kirman bölgeleriyle birlikte kalay madenleri yönünden de zengin yataklara sahip olduğunu unutmamak gerekir.

MS. 530-540 yılları arasında, Sâsânî hükümdarı I. Hüsrev Enûşirvân'ın yapmış olduğu toprak reformu kapsamında askerler ve din adamları vergi dışında tutulmuştur ${ }^{144}$. Bu dönemde önemli vergi gelirine sahip olan Tebriz şehrinin, ne gibi bir durumla karşı karşıya kaldığına dair herhangi bir bilgiye rastlanmaz. Fakat devlet arazisinin, toprağın üzerinde yaşayan halka dağıtılması ve yetiştirilen ürünün şekline göre vergiye tabi tutulmasının yanında din adamları ve askeri sınıfın vergiden muaf tutulması; askeri ve dini özelliğe sahip bu şehrin Enuşirvan döneminde güçlü bir refah düzeyine ulaşmış olduğu kanısını beraberinde getirebilirr ${ }^{145}$.

\section{Tebriz'in Sosyal, Fiziksel, Kültürel ve Dinsel Özellikleri}

Sâsânîler döneminde Azerbaycan toplumunun, İranî bir halktan meydana geldiği ve daha sonraları Ortaçağlardaki Türk akınlarından dolayı bu halkın, Selçuklu-Oğuz Türkleriyle kaynaşarak günümüz Azeri Türklerini meydana getirdiği iddia edilmektedir ${ }^{146}$. Oysa Sâsânîler döneminde Azerbaycan toprakları üzerinde yaşayan halkın ve Tebriz'in sosyal yapısı homojen bir özelliğe sahip değildi. Tebriz toplumu içerisinde Turanî, Aryen, Süryani, Ermeni gibi birçok topluluklar bulunmaktaydı. Bunun yanında şehir halkının büyük bir kısmının Sakalardan meydana geldiği de bilinmektedir. Sâsânî hükümdarı I. Hüsrev Enûşirvân, kendisinden önceki hükümdarların aksine, diğer Türk boylarının Kafkasların güneyine inmelerine izin vermiş ve bu

\footnotetext{
${ }^{141}$ Wiesehöfer 2003, s.278.

${ }^{142}$ Barthold 1975, s.87.

${ }^{143}$ Daryaee 2010, s.405.

144 Tefazzulî 1995, s.255.

${ }^{145}$ Enuşirvan'ın yapmış olduğu bu uygulamalar hakkında geniş bilgi için bkz. İbnu'l-Belhî 2008 .

${ }^{146}$ Naroditskaya 2002, s.13; Ağaoğlu 2002, s.218-219.
} 
dönemde Tebriz kentindeki Türk nüfusu iyice artmaya başlamıştı. Hatta MS. 532 y1lında şehir nüfusunun büyük bir kısmı Hun, Sabir, Ogur, Kuşan, Hazar ve Abhazlardan meydana gelmekteydi ${ }^{147}$. Bundan dolayı Aryen, Turan ve Kafkas topluluklarının yaşadığı şehrin demografik yapısının heterojen bir özelliğe sahip olduğu görülmektedir.

Sosyal olarak Sâsânî toplumunda görülen sinıfsal yap1, Tebriz şehrinde de kendisini belirgin bir şekilde göstermekteydi. Şehrin sahip olduğu dinsel yapıdan dolayı, asravan adı verilen ruhban sınıfı önemli bir mevkie sahipti ve bu sınıf mensupları yargıçlık ile yüksek rütbeli sivil memuriyetleri ellerinde bulunduruyorlard1 ${ }^{148}$. Arteşrevan adı verilen; ordu yönetimi, komutanlıklar ve eyalet valiliklerini elinde bulunduran savaşçı ve askeri sınıfı oluşturan memurlar ise mûbed $^{149}$ adı verilen din adamlarından sonra ikinci sınıfı oluşturmasına rağmen, ordu komutanı şehrin hâkimi sayılmaktayd ${ }^{150}$. Tabiplik, öğretmenlik ve kâtiplik görevinde bulunan memurlar ise dibheran adı verilen sosyal yapıyı oluşturuyordu. Toplumdaki en kalabalık sınıfı ise vastaryoşan adı verilen ziraat ve zanaat ile uğraşan geniş halk kitlesi meydana getiriyordu ${ }^{151}$. Fakat Erken Ortaçağlarda ve özellikle Sâsânîler döneminde şehrin sosyal yapısının önemli bir kısmını askerler ve din adamları oluşturmaktaydı. Bu ise şehrin askeri ve dini yapısından kaynaklanmaktaydı. Şehir halkının çoğu askerlik mesleği ve dinsel görevlerle uğraşırlardı. Şehrin askeri özelliği Arşakîler döneminden gelmekteydi. Arşakîlerden sonra Ermeniler buranın askeri yapısını daha da geliştirdiler. Tebriz şehrinin bu sosyolojik özelliği, Sâsânîler döneminde de hiç değişmeden devam etti. Bununla beraber Tebriz şehri, Sâsânî şehzâdelerinin yetiştirildiği önemli şehirlerden biriydi ve birçok hanedan üyesi bu şehirde valilik yapmışt ${ }^{152}$.

Müslümanların, Sâsânî devletini yıkmasından sonra şehrin demografik yapısı değişmiş ve Tebriz şehri çoğunlukla Arap, İran, Adurî, Ermeni ve göçebe Türk topluluklarından oluşmaya başlamıştır. Erken Ortaçağların sonlarında özellikle Abbasi-Türk ilişkilerinin gelişmesi sonucunda şehir, Orta Asya'dan

\footnotetext{
${ }^{147}$ Kristensen 1368 hş, s.392.

${ }^{148}$ Nefisi 1331h, s.1.

149 Sâsânî devletinde "athravan" adı verilen din adamları sınıfındaki memurlara verilen isimdi. Bunlara "mubaz", hirbad", "mag" veya "magan" isimleri de verilmekteydi. Bkz. Nefisi 1331hş, s.1. Sâsânîlerde her eyaletin bir mubad'ı olurdu. Bkz. Kristensen 1368hș, s.148. Bu mubadlar tapınaklarda görev yaparlardı. Onların başında ise Zerdüştlük dininin papası sayılabilecek olan "mubad-ı mubad" adı verilen en büyük din adamı bulunmaktaydı. Bkz. Behnam 1337h, s.184.

${ }^{150}$ Altungök 2006, s.72.

${ }^{151}$ Sarfaraz 1996, s.244.

152 Jackson 1906, s.41.
} 
kopup gelen Türklerle dolup taşmaya başlad1 ${ }^{153}$. Bu Türk göçlerinden önce buradaki Sakalardan kalma Türk varlığı ise, Adurî olarak adlandırılmaktaydı.

Yakut el-Hamevî, Hicrî IV. yüzyılda Tebriz'in, Azerbaycan'in en büyük ve en meşhur kenti olduğunu ifade etmektedir ${ }^{154}$. Yakut'a göre Tebriz şehri Azerbaycan ülkesinin merkezidir. İbnu'l-Havkal, Hicrî 367, İbnu'l-Meskube Hicrî 421, Nasır-1 Hüsrev Hicrî 438 yılında Tebriz'in, Azerbaycan'ın en bayındır ve en büyük şehri olduğunu dile getirirken, el-Belazurî, et-Taberî ve elİstahrî gibi tarihçi ve coğrafyacı bilim adamları ise Tebriz'i, Azerbaycan'ın küçük şehirlerinden biri olarak tanıtırlar ${ }^{155} . \mathrm{Bu}$ durum, Tebriz şehrinin bu coğrafyacıların yaşadığı dönemde eski önemini yitirmiş olmasından kaynaklanmaktaydı. İbnu'l-Miskeveyh'e göre, Tebriz halkı cesur, savaşçı ve zengin insanlardan oluşmaktadır. İbnu'l-Havkal kendi yaşamış olduğu dönemdeki Tebriz'in bayındır, kalabalık, kazanç getiren, geliri yükssek ve güzel bir şehir olduğunu ifade etmektedir ${ }^{156}$. Aynı yazar, buranın ayrıca çok sayıda pazara ve alışveriş yerlerine sahip olduğunu da belirtmektedir. O dönemde Tebriz'in Azerbaycan'ın başşehri ve en bayındır şehri olduğunu belirtir. İbnu'lHavkal, Tebriz insanlarının soğukkanlı ve sert tabiatlı olduğunu söyleyerek, bunu da şehrin sert iklimine yormaktadır ${ }^{157}$. Ayrıca şehrin oldukça sağlıklı bir havası vardı ve şehir, tıp bilimi ile tıbbi çalışmalarda gelişmiş bir düzeydeydi ${ }^{158}$.

Nasır Hüsrev, Miladi 11. yüzyılda Tebriz şehrinin 1400 adıma 1400 adım genişliğinde bir alana sahip bir şehir olduğunu belirtmektedir. Şehrin surlarla çevrili bir iç kaleye sahip olduğunu ve bu surların dışında bahçelerle çevrili şehrin dış mahallelerinin yer aldığını ifade eder. Etrafı surlarla çevrili şehrin hükümet binası, pazarı ve şehir camisi bu alanın içerisinde olmakla beraber; dış mahallelerinden başlayan köy ve kasabaları batıda Urumiye gölüne ve güneyde Genzek kasabasına kadar uzanmaktayd ${ }^{159}$.

Sâsânîlerin meşhur tapınakları olan Adhur Gushnasb (Azer Geşnesb) bu bölgede bulunmaktayd ${ }^{160}$. İran toprakları üzerinde bulunan ateş tapınaklarının merkezi olması hasebiyle bu tapınağa Kâbe-i Zerdüşt adı verilmiştir. Bu tapınak Sâsânîler dönemi Zerdüştlügün en önemli dini mekânı olarak kabul edilmektedir ${ }^{161}$. Adhur Gushnasb, İslam sonrası dönemde Taht-ı Süleymân

\footnotetext{
${ }^{153}$ Bosworth 1968, s.44vd.

${ }^{154}$ Christensen 1993, s.211; Strange 2011, s.161.

${ }^{155}$ Minorsky 1337hş, s.12; Barthold 1975, VIII-XII, s.87vd; Madelung 1975, s.233.

${ }^{156}$ Madelung 1975, 233; Minorsky 1964, s.83-85.

${ }^{157}$ İbnu'l-Havkal 1338h, s.84.

${ }^{158}$ Elgood 2010, s.311.

${ }^{159}$ Christensen 1993, s.211; Minorsky 1964, s.86.

${ }^{160}$ Ayatolahi 2002, s.103, 129, 131. Vaux 1900, s.304; Rawlinson 1841, s.107.

${ }^{161}$ Girişmen 1336, s.318.
} 
şeklinde meşhur olmuştur. Sâsânî hükümdarı V. Behram ile Akhunlar arasında yapılan Maveraünnehir savaşlarından sonra, Akhun hükümdarını yenerek onu ele geçiren V. Behram, Akhun hükümdarının tacını, tahtını ve ailesini bu tapınağa hediye olarak yollamıştır ${ }^{162}$. Sâsânî hükümdarları, halklarının itaatini ve bağlılığını bu tapınaklara hürmet etmekle elde etmeye çalışmışlardır. Ayrıca siyasi çekişmelerden dolayı zor durumda kalan Sâsânî hükümdarları kaçarak Tebriz'deki tapınaklara sığınma yolunu seçmişlerdir ${ }^{163}$.

Genzek kasabasında Sâsânîler döneminde MS. 5. yüzyılın sonlarına doğru büyük bir Nesturî piskoposluğu açılmıştır. Azerbaycan ve merkezi konumunda olan Tebriz kenti, Sâsânîler döneminde dinsel fikir ve faaliyetlerin yoğun bir şekilde yaşandığ 1 bir eyalet özelliği taşımaktadır. Bu nedenle buralara Magların ülkesi adı da verilmekteydi ${ }^{164}$. Tebriz'in yanında Erdebil, Meraga, Urumiye gibi Azerbaycan kentleri birçok tapınağa sahiptiler ve bu tapınaklar, Adhur Gushnasb tapınağına bağlıydılar ${ }^{165}$. Bizans imparatoru Herakleios MS. 628 yılında Sâsânî hükümdarı II. Hüsrev ile yaptığı Ninova savaşından sonra Adhur Gushnasb tapınağını yerle bir ettirmiştir. Bu tapınağın içerisinde bulunduğu külliye, daha sonraları İslamî dönemde tamir edilerek yazlık saray olarak kullanılmıştır ${ }^{166}$.

Anılan Azerbaycan kentleri, Sâsânîler için dinsel merkezler konumundaydılar ve Zerdüşlük inancı buralarda kök salmıştı. Bu da Zerdüşt’ün Azerbaycanlı olması ve burada yürütmüş olduğu inançsal faaliyetlerden kaynaklanmaktayd $1^{167}$. Zerdüştlüğün yanında Azerbaycan topraklarında ay, güneş ve yıldızlar da kutsanıyordu. Strabon, bu topraklarda Göktanrı inancının da yaygın olduğunu söylemektedir ${ }^{168}$. Göktanrı inancının Sakalar tarafından bu bölgeye getirildiği zannedilmekle beraber, Kafkaslarda yerleşik olan diğer Türk boylarında da Göktanrı inanc1 olabileceği ihtimali güçlüdür. Göktanrı inancındaki kutsal ateş kültürünün de, Zerdüştlük inancına sonradan girmiş olduğu söylenmektedir. Zerdüşs inancının başlangıç safhasında bulunmayan ateş kültü, Göktanrı inancından alındıktan sonra Mecusiler tarafından ateşe tapınma aracı olarak kullanılmıştır.

Anılan bölge ve şehirler aynı zamanda Hıristiyanlığın da en kuvvetli merkezleri durumundaydı. Sâsânîler, Azerbaycan topraklarını elde tutabilmek amacıyla burayı Zerdüşt inancının merkezi haline getirerek Bizans nüfuzunu

\footnotetext{
${ }^{162}$ Minorsky 1964, s.224; Girişmen 1336h, s.359.

${ }^{163}$ Jonston 2006, s.74. Ayrıca daha geniş bilgi için bkz. İbnu'l-Belhî 2008.

${ }^{164}$ Girişmen 1336h, s.318.

165 Rawlinson 1841, s. 107.

${ }^{166}$ Rossabi 2010, s.104.

${ }^{167}$ Can 1968, s.281.

${ }^{168}$ Gurbanov 2007, s.27-28.
} 
önlemeye çalışmışlardır. Bunun yanında Bizanslılar da Sâsânî nüfuzunu kırmak amaciyla Kebele ${ }^{169}$ şehrini Kudüs'ten sonra ikinci büyük dini merkez haline getirmişlerdir $^{170}$. Manîlik veya Maniheizm ${ }^{171}$, yöredeki diğer önemli bir inanç sistemiydi. Medâ'inli bir din adamı olan Mani'nin ilk ziyaretini Azerbaycan'a yapmış olması bu toprakların dinsel açıdan önemli bir yere sahip olmasından kaynaklaniyordu ${ }^{172}$.

\section{Tebriz Halkının Dili}

Tebriz ahalisinin konuşmuş olduğu dil; Hazarlar ${ }^{173}$, $1 \mathrm{n}$ da konuşmuş oldukları eski Saka ve Manna dillerinin farklı bir şeklidir ${ }^{174}$. Bu dilin sözcük anlamı, Hadari/Hazari veya Aduri/Adari ${ }^{175}$ kelimelerine dayanmaktadır. Bu konuda en uygun görüş ise, bu dilin sözcük anlamını, Azerbaycan'a adını vermiş olan "Adur" kelimesinden almış olduğudur ${ }^{176}$. "Adur" sözcüğü günümüzde Sakaların devamı olan Zaza ${ }^{177}$ ve Azeri dillerinde de ateş sözcüğünün karşıllğı olarak kullanılmaktadır ${ }^{178}$. Bu sözcük eski Saka diline ait olmakla birlikte kaynağını, Öz Türkçe bir sözcük olan ve daha sonraları Fars diline de girmiş olan "od" (ateş) kelimesinden almıştır. Adur sözcüğü, od

\footnotetext{
${ }^{169}$ Kebele: Kuzey Azerbaycan'da kurulmuş olan Albanya Devletinin başkenti olan Kebele şehri, günümüz Gence bölgesi şehirleri arasında sayılmaktadır. Hıristiyanlığı kabul etmiş olan Albanların bütün kiliseleri bu şehirdeki ana kiliseye bağlıydı. Bkz. Memmedova 1993, s.207.

${ }^{170}$ Gurbanov 2007, s.33.

171 Maniheizm; Sâsânî başkenti Tisfun şehrinde MS. 216 yılında dünyaya gelen kendisini peygamber olarak kabul eden Mani adındaki bir din adamının ortaya koymuş olduğu, iyilik ve kötülüğün savaşımına dayanan düalist bir inançtır. Mani inancı, Ortadoğu'da ortaya çıkan bütün dinlerin bir sentezi gibidir. Mani kendi felsefi mantığında Yahudiliği, Hıristiyanlığı ve Zerdüştlüğü birleştirmiş ve Zerdüşt dininin ıslahı için ortaya çıktığını söylemiştir. Bkz. Rudolph 2002, I, s.378-393.

${ }^{172}$ Henrichs 1979, s.347.

${ }^{173}$ Hazarlar: Hazar isminin Saka ve Sarmatlara verilen bir isim olduğu söylenmektedir. Normalde Hazar adı verilen bir milletin olmadığı, Kafkasya ve Hazar Denizi'nin batısı ile kuzeyinde meskûn bulunan Türk göçebe boylarının hepsine verilen ortak bir isim olduğu ifade edilir. İbnu'l-Havkal ve İstahri, Hazar'ın bir millet değil de başkenti İtil olan bir ülke olduğunu söylerler. Bkz. Yumanadi 2002, s.464.

${ }^{174}$ Dalby 2004, s.496.

${ }^{175}$ Minorsky 1957, s.112.

${ }^{176}$ Rawlinson 1841, s.107.

${ }^{177}$ Zazaca: Günümüzde iki milyona yakın insanın konuştuğu varsayılan, Batı İran ve Azerbaycan dillerinden kabul edilen Saka kökenli bir dildir. Şu an Doğu Anadolu ve Güney Azerbaycan bölgelerinde kullanım alanına sahip olan bu dilin, Azeri Türkçesi ile olan ortak sözcükleri ilginç bir konuyu teşkil etmekle beraber bu durum iki toplumun da Saka kökenli olmasından kaynaklanmaktadır. Bkz. Mann 1932, s.18.

${ }^{178}$ Ludwing (Trz), s.163-176. Bunun yanında Minorsky, Gazaca sözcüğünün aslını Zazaca'dan aldığını söyler. Bkz. Minorsky 1964, s.243-265.
} 
kelimesinin sonuna yer ve ülke anlamı katan ar ekinin getirilmesiyle od-ur, ad$u r$ şeklinde türetilmesi sonucunda elde edilmiştir ${ }^{179}$. Böylece bu sözcük ateşin halkı anlamına gelmekle beraber Farsça'ya "azer" şeklinde geçmiş ve ateş anlamında kullanılmıştır ${ }^{180}$. Bu sözcüğün Farsça "azer" olarak telaffuz edilmesinin nedeni "adhur" sözcüğündeki "dh" telaffuzunun Orta Farsçadaki "dat" harfinin "zat" şeklinde okunmasından kaynaklanır ${ }^{181}$. Bu bölge halkının kullanmış olduğu dil, ateş halkının dili anlamında Adurî şeklinde ifade edilmiş ve sonraları Azerî şeklini almıştı1 ${ }^{182}$.

$\mathrm{Bu}$ telaffuz, Saka-Aryen dil eşiği açısından iki toplumun da konuşmuş oldukları dilin birbirine yakınlık göstermesi açısından Sâsânîler tarafından da aynen kullanılmışır. Eski Saka, Zaza ve Hazar dillerinin farklı bir türevi olan Aduri dili; Tebriz kentinin, Ön Asya'ya Türk göçlerinin gerçekleştiği dönemlerde, Türkmenler tarafından iskânıyla beraber, Selçuklu ağziyla birleşmiş ve bugünkü Azeri dilini ortaya çıkarmıştır. Buna göre, "od" sözcügünün çekiminde kullanılan "ar-er" eki, millet yapan bir ektir. Bunun örneğini "Hazar" sözcüğünde bulmak mümkündür. "Gez" veya "Guz" sözcüğüne "ar" ekini getirmek suretiyle bir millet ismi olarak türetilen Guzar (Hazar) sözcüğü, buna verilebilecek en güzel örneği teşkil etmektedir ${ }^{183}$. Yine diğer Türk kavimlerinin ismi olan Sabar, Avar, Uygur, Ogur gibi sözcüklerin sonunda bulunan ar, er, ur gibi ekler de buna verilebilecek örnekler arasındadır.

Azeri dili, Sâsânîler döneminin önemli bilim ve felsefe diliydi ve özellikle sanat ve müzik alanında önemli bir konuma sahipti. Şiir ve müzikteki usta kullanımı, Sâsânîler döneminden sonra İslamî dönemi önemli ölçüde etkilemiş ve İslamî dönemin önemli şair ve müzisyenlerini de ortaya çıkarmıştır ${ }^{184}$. Bunun yanında yine Saka menşeli bir dil olan Dari ${ }^{185}$ dili de Tebriz şehrinde konuşulan diğer bir dil idi. Fakat bu dil Saka-Pers kaynaşması sonucunda Farsçalaşmış ve Eski Farsçanın bir şivesini oluşturmuştur. Ancak bu dil, Erken Ortaçağlarda genelde İranlılarla kaynaşmış Türklerin konuştukları bir dildir ki genelde Maveraünnehir, Horasan ve Buhara'da konuşulmaktayd ${ }^{186}$.

\footnotetext{
${ }^{179}$ Dalby 2004, s.496.

${ }^{180}$ Mütercim Asım Efendi, Burhan-1 Katı'da, “Ateş, zeban-1 Türkî’de, od demektir” diyerek bu sözcüğün öz Türkçe olduğunu ifade eder. Bkz. Mütercim Asım Efendi 2000, s.28.

${ }^{181}$ Houtsma 1936, s.134; Kâmûs-u Türkî'de, Fars dilinde ateşe, "azer", Türk dilinde ise "od" denildiği ifade edilmektedir. Bkz. Turan 2008, s.868.

182 Bilgili 2002, s.22.

${ }^{183}$ Yücel 2002, s.445.

${ }^{184}$ Naroditskaya 2002, s.13vd.

${ }^{185}$ Derî Dili: Adındaki saray anlamındaki dar/der sözcüğünden yola çıkılarak, saray dili anlamına geldiği ifade edilmektedir. Derî Farsçasıyla kastedilen dilin, yeni farsça olduğu da söylenir. Huart 1963, s.542.

${ }^{186}$ İbnu'l-Havkal 1338h, s.216.
} 
Bununla birlikte XI. yüzyıla kadar Tebriz şehrinde hiçbir şekilde Türk dillerinin konuşulmadığı, ancak Selçuklu döneminden itibaren Tebriz'e yerleşen Türklerin yerel Adurî dilini konuşmasıyla bugünkü Azeri dilinin ortaya çıktığ1 da ileri sürülmektedir ${ }^{187}$. Zekeriya Muhammed el-Kazvinî ise, "Âsâru'l-Bilâd ve Ahbâru'l-i̇bâd" adlı eserinde, Türklerin Tebriz hariç bütün İran ülkesine hâkim olabildiklerini, ancak Tebriz'e sahip olamadıklarını ifade ederek Tebriz'in, Türkçenin nüfuz alanının dışında kaldığını iddia eder. Anılan yazar, bununla da yetinmeyerek Tebriz'de XIV ve XV. yüzyıla kadar Dari ve Farsçanın dışında hiçbir dilin konuşulmadığını da ileri sürmektedir ${ }^{188}$. Oysa yazar, Darî dilinin, Sakaların devamı niteliğindeki Adurî dilinin Farsçalaşmış şekli olduğunu göz ardı etmektedir. Şüphesiz ki, bu dilin hem Azerbaycan hem de Horasan'da konuşulan Saka dilinin Farsçalaşmış bir şekli olması sebebiyle, bu bölgenin geçmişinde Türkçenin aktif bir şekilde yer aldığını göstermektedir.

\section{Tebriz'in Mimarisi}

Tebriz, Sâsânî dönemi eyalet ordularından Adurbadegan eyaletinin ${ }^{189}$ merkezi olduğundan dolayı şehirde eyalet sarayı ve ordu karargâhı bulunmaktaydı. Eyalet sarayı, hem Sâsânî eyalet yöneticilerinin hem de Sâsânî prenslerinin ikamet ettiği yerdi. Sâsânî devletinde eyalet komutanları kendi merkezlerindeki eyalet saraylarında gümüş taht üzerinde otururken, Azerbaycan eyalet valisi altın taht üzerine oturmaktayd $1^{190}$. Bu durum, Sâsânî hükümdarının özel izninden kaynaklanmakla beraber, Azerbaycan satraplığının Sâsânî hükümdarları nezdindeki kıymetini göstermekteydi. Hükümdarlar da Kafkasya üzerine yapmış oldukları seferler sırasında bu şehre geldiklerinde eyalet sarayında kalırlardi.

Sarayın önünde hükümdarlara ait heykeller bulunurdu. II. Tiridates, Tebriz şehrine girip eyalet sarayının önüne geldiğinde burada bulunan Şapur'un heykelini ok yağmuruna tutarak ona olan öfkesini ortaya koymuştur. Eyalet sarayının kubbeli çatı kısmında II. Hüsrev'in başında taç takılı bir tasviri bulunmaktaydı. $\mathrm{Bu}$ tasvirde, II. Hüsrev başında tacıyla beraber Cennet'e girmekte; güneş, ay ve yıldızlar onun etrafında dönmekteydiler ${ }^{191}$. Bizans

\footnotetext{
${ }^{187}$ Jean Druing 2003, s.172.

188 el-Kazvinî 1960, s.339; Khoi (Trz.), s.180-181.

${ }^{189}$ Sâsânî devleti bünyesinde birçok eyalet olup bunlar dört ana eyalet çatısı altında toplanmıştı. $\mathrm{Bu}$ dört ana eyaletten her birine satrap adı verilmekteydi. Bu kelime, eski Pehlevice yazıtlarında özellikle Ahamanişler dönemi yazıtlarında, ksatrapa olarak geçmektedir. Bu kavram sonraki dönemlerde sınır muhafizı anlamına gelen merzbân şeklini almıştır. Bkz. Behnam 1337h, s.186; Meşkür 1366h, s.105.

${ }^{190}$ Nicolle 1996, s.10.

${ }^{191}$ Brill 1955, s.484.
} 
hükümdarı Herakleios Tebriz'i ele geçirdikten sonra bu tasviri parçalatmıştır. Bunun yanında Tebriz'deki hükümdarlık sarayı, Tebriz şehrinin surlarla çevrili iç kısmında bulunmaktaydı. Fakat şehrin ordugâhı ise surların dışındaki alana inşa edilmişti.

$\mathrm{Bu}$ kentin binaları meşhur Tebriz mermeriyle yapılmaktaydı. Erken Ortaçağlarda Adurbadegan bölgesi, mermeri ile meşhurdu. Özellikle en kaliteli mermer, Tebriz şehrine aitti ${ }^{192}$. Tebriz şehrinin volkanik bir arazi üzerinde kurulmuş olmasından dolayı sahip olduğu gevşek yapı nedeniyle ve depremlerle sürekli yıkıma uğraması sebebiyle bu şehirde yapılan binalar tek veya iki katlı binalardan oluşmaktayd ${ }^{193}$. Bununla beraber şehrin mimarisinin askeri ve dini bir mimari tarzında olduğunu, buranın askeri ve dinsel yapısından anlamaktayız.

Tebriz kentinin ticari yönünden dolayı sahip olduğu pazarlar, çarşılar ve imalathaneler de önemli bir yere sahipti. Çünkü Tebriz şehri, Sâsânî ve Kafkas kavimleri arasında uzanan kuzey-güney ticaret yolu veya daha açık bir deyişle İpek yolunun kuzey-güney kavşak noktası üzerinde bulunmaktaydı. İbnu'lMiskeveyh, Tebriz şehrinin etrafının sağlam surlarla çevrili, aynı zamanda ağaçlar ve bahçelere sahip müreffeh bir şehir olduğunu zikretmektedir ${ }^{194}$. Erken Ortaçağlarda mevcut olan eski şehrin etrafinda bulunan bu surların uzunluğunun 6.000 adım olduğu da söylenmektedir ${ }^{195}$.

Tebriz şehri de klasik Ortaçağ şehirleri gibi, etrafı surlarla çevrili bir iç şehir ile bu şehrin dışında köy ve kasabalara kadar uzanan ve şehrin diğer mahalleleri ile çevrili bir diş şehirden oluşmaktayd1 ${ }^{196}$. Sâsânîlerden önce şehrin çevresinin tamamen surlarla, bu surların etrafının ise, içi suyla dolu geniş bir hendekle çevrili olduğu Asur metinlerinden anlaşılmaktadır. Şehir büyüdükçe hendeğin içi dolmuş ve böylece surlardan itibaren etrafı dış mahallerle çevrili bir şehir haline gelmiştir. Bu şehirde inşa edilen kalelerin genel olarak etrafinda su dolu hendekler bulunurdu. Günümüzde Taşkale adı verilen ve Sâsânîler döneminde askeri bir garnizon olarak kullanılan kalenin etrafını, Sehend dağından kaynağını alan bir nehir dolanmaktadır. Dezziya Rûd adı verilen bu suyun üzerinde, Sâsânîler döneminde su kemerleri ve sulama kanalları için oluşturulmuş bir set inşa edilmişti ${ }^{197}$. Sâsânî devletinin kurulduğu ilk yıllarda

\footnotetext{
${ }^{192}$ Rawlinson 2005, s.29.

${ }^{193}$ Fisher 1978, s.31.

${ }^{194}$ Minorsky 1965, s.83.

195 Nühzetu'l-Kulûb'a göre, Gazan Han döneminde büyüyen ve genişleyen Tebriz şehrinin etrafındaki surlar, yeni mahalleler ve köyleri de içine alacak şekilde genişletilmiş ve şehir surlarının uzunluğu 25.000 adıma ulaşmıştır. Bkz. Barthold 1975, s.81.

${ }^{196}$ Minorsky 1337hş, s.12; Jackson 1906, s.41; Diakonof 1985, s.86.

${ }^{197}$ Rawlinson 1841, s.10, 11.
} 
Tebriz'i ele geçiren Arşak hükümdarı II. Tiridates, Tebriz'in surlarla çevrili iç kısmına bir kale daha yaptırmıştır ${ }^{198}$.

Sâsânîler döneminde Sehend dağından kaynağını alan çok sayıda akarsuyun üzerine bu dönemde köprüler inşa edilmişti. Bu köprülerden günümüze kadar ulaşanlardan bir tanesi Pol-i Dokhtar (Kız Köprüsü) adı verilen köprüdür. $\mathrm{Bu}$ köprü irice kesme taşlardan yapılmış 18 adım uzunluğunda ve 8 adım genişliğindedir ${ }^{199}$. Tebriz şehrinin Sâsânîler dönemindeki genel görünümü; kaleler, tapınaklar ve köprüler arasında dağılmış evler ve bunların etrafında geniş bir alana yayılan bahçeler şeklindeydi. Tiridates, Tebriz şehrini Sâsânîlerin elinden aldıktan sonra eski Babil ve Ekbatana şehirlerinde olduğu gibi, bu şehrin birçok yerine MS. 303 yilında asma bahçeler yaptırmıştı ${ }^{200}$. Bu dönemde Tebriz'in Ekbatana şehrine rakip olabilecek düzeyde bir görünüme kavuştuğu söylenmektedir ${ }^{201}$.

\section{Sonuç}

Dünyanın en eski uygarlık merkezlerinden birisi olan Tebriz, yaklaşık olarak altı bin yıllık bir tarihe sahiptir. Kimler tarafindan kurulduğu tam olarak bilinmese de, tarih boyunca Türklerin yoğunlukta olduğu bir şehir olduğu görülmektedir. Tebriz şehri adını ise büyük bir olasılıkla Sakaların Kafkaslara egemen oldukları dönemde almıştır. Adurbadegan adı verilen güney Azerbaycan topraklarının merkezi olan Tebriz şehri, İran medeniyetini derinden etkileyen önemli bir şehir olarak Erken Ortaçağların önemli bir uygarlık merkeziydi. Burası, Sâsânî devletinin ilk dönemlerinde, Ermeni ve diğer Kafkas halklarıyla yapılan savaşların odak noktasında bulunmasından dolayı, askeri bir garnizon şehir kimliğine bürünmüştür. Bu dönemdeki fiziki yapısı, genellikle askeri yapılar, ordugâhlar ve komutanlara ait köşklerden oluşmaktaydı. Fakat Sâsânî devletinin, Tebriz'deki egemenliğini sağlama aldığı Miladî 240'l1 yıllardan sonra, şehir tamamen bu devletin dini bir merkezi haline gelmiştir. Tebriz şehri, bu özelliğiyle İran milli inancı olan Zerdüştlüğün çıkış noktası ve ana merkezidir. Bunun dışında Sâsânî devletini sosyal açıdan etkileyen Mazdek ve Mani inançları da güçlerini yine bu şehirden alarak yayılmaya başlamıştır. Bütün bu gelişmelerden ötürü Tebriz kenti dini ve kültürel açıdan Sâsânî devletinin önemli şehirlerinden birisi haline gelmiştir. Sâsânî devletinin mobad adı verilen din adamları tarafindan yönetilmesi ve bu din adamlarının Tebriz

\footnotetext{
198 Reisneya (Trz), s.445.

199 Rawlinson 1841, s.42.

${ }^{200}$ Porter 1822, s.97.

${ }^{201}$ Malcolm 1806, s.546.
} 
şehrini merkez olarak kullanmaları, Tebriz kentinin Sâsânîlerin kültürel ve dini başkenti olmasını sağlamıştır.

Günümüz Tebriz'i ne üzücüdür ki Erken Ortaçağlara ait fazla bir esere sahip değildir. Bunun temel nedeni, işgaller sonucu yıkılmasının yanında uğramış olduğu yıkıcı depremlerin sonucunda yerle bir olmasından kaynaklanmaktadır. Depremlerin Tebriz şehrine vermiş olduğu yıkımlardan sonra en büyük yıkımı Bizanslılar gerçekleştirmişlerdir. Tebriz kenti, Bizanslıların dinsel öfkelerinin kurbanı olmuştur. Öyle ki Sâsânîlerin dinsel başkenti konumunda olan Tebriz şehri, Sâsânîlerin Kudüs şehrinde yapmış oldukları Hıristiyan katliamına karşı Bizanslılar tarafından adeta yerle bir edilmiştir. Bizans-Hazar ittifakı neticesinde Sâsânî imparatorluğunun batı kısımlarını ve Adurbadegan topraklarını ele geçiren Hazarlar ve Bizanslılar, Sâsânî şehirlerini büyük bir yıkıma uğratmışlardır. Özellikle Herakleios, Tebriz kentini yerle bir ederek şehirdeki büyük tapınakları, şah saraylarını ve ordugâhları yıkarak şehrin mimarisini ortadan kaldırmıştır. Bu işgal hareketi, Tebriz şehrinin Erken Ortaçağlara ait diğer kalıntılarının da ortadan kalkmasına neden olmuştur. Tebriz şehrinin sahip olduğu ticari ve ekonomik özellikten dolayı, tarihin birçok döneminde defalarca inşa edilmiştir. Ekonomik ve jeopolitik öneminden dolayı Azerbaycan topraklarına sahip olan hanedanların bir türlü vazgeçemediği bu şehir, kimi zamanlar küçük bir köy, kimi zamanlar ise küçük bir kasaba olarak varlığını devam ettirse de, daha sonraları büyük bir şehir olarak tekrar inşa edilmiş ve eski canlılığına tekrar kavuşabilmiştir.

Tebriz, Türk şehri vasfını Erken Ortaçağlarda devam ettirmiş ve halkı hemen hemen günümüz Türkçesine yakın bir dili kullanmıştır. Bunun yanında bazı dönemlerde İran, Ermeni ve Arap nüfusunun şehrin çoğunluğunu oluşturduğu dönemlere da tanıklık etmiştir. Adurbadegan topraklarının sahip olduğu ateş kültünden dolayı, bu toprakların başkenti olan Tebriz hep ateş sözcüğü ile anılmış, bu ise burada yaşayan Türklerin, Adhuri şeklinde anılmasına neden olmuş, onların konuştukları dil de aynı adla adlandırılmıştır. Günümüz Azeri halkı ve konuştukları dil, Oğuzların Azerbaycan topraklarına akınları ile buradaki halklarla kaynaşmalarından sonra ortaya çıkmış olmasına karşın, Erken Ortaçağlardaki Adurbadegan halkı içerisindeki Türk unsurları genel olarak Sakalara dayanıyordu. Saka, Manna ve Kaspi karışımı bir topluluk iken Aryen halklariyla münasebetleri neticesinde bugünkü Tebriz merkezli Azerbaycan toprakları üzerinde adına Adhuri denilen Azeri Türkleri ortaya çıkmıştır. O dönemlerde de konuşmuş oldukları Saka orijinli dillerine, Aduri dili adı verilmekteydi ve bugünkü Azeri diline oldukça yakın bir fonetiğe sahipti.

Müslümanların, Sâsânî devletini yıkmalarından sonra, bütün İran, Azerbaycan ve Irak topraklarına hâkim olmaları ile birlikte, Tebriz şehrindeki Azeri varlığı Erdebil'e doğru kaymış ve Güney Azerbaycan topraklarının 
merkezi özelliği Tebriz şehrinden Erdebil şehrine geçmiştir. Bu dönemden, Azerbaycan'a yapılan Oğuz göçlerinin başladığı döneme kadar Tebriz şehri Sacîler dönemi dışında, Arap-Kürt karışımı halkların merkezi haline gelmiş, ancak Oğuz akınları sonucunda bölge yine Azeri nüfusunun kontrolü altına girmiştir. Tebriz şehri Sâsânîlerin yıkılmasından sonraki dönemlerde, çoğu zamanlar küçük bir köy veya kasaba şeklinde varlığını devam ettirmiş, bu esnada sadece Sacîler ve Revvâdîler döneminde eski canlılığını koruyabilmiştir. $\mathrm{Bu}$ dönemlerde Tebriz şehri, Erken Ortaçağların etrafı surlarla ve duvarlarla çevrili tipik şehir tarzının yerini, çeşitli köy, kasaba ve mahallelerden oluşan çarşı, pazarı ve hükümet merkezinin büyük bir kalenin içinde bulunduğu klasik ileri dönem bir Ortaçağ şehrine dönüşmüştür. 


\section{KAYNAKLAR}

Abdurrahman 2004

Ağaoğlu 2002

Akiner 1983

Aksoy 2002

Altungök 2006

Ambraseys 1982

Arrowsmith 1839

Arrowsmith ve Nicolay 1856

Arrowsmith, Aaron - Nicolay, C. G., A Compendium of Ancient

Ayatolahi 2002

Bakır 2005

Baratova 2002

Barthold 1308hş

Barthold 1963

Barthold 1975

Behnam 1337hş

Benjamin 1891

Bilgili 2002

Bilgili 2011

Bosworth 1968

Abdurrahman, Varis, "Tarihteki Efsanevi Turan Padişahı Alper Tunga Hakkında", Tarih Araştırmaları Dergisi, XXII-35, s.1-8. Ağaoğlu, Elnur "Azerbaycan'ın Etnik ve Demografik Yapısı", Türkler, c. XIX, Yeni Türkiye Yayınları, Ankara, s.218-219.

Akiner, Shirin, Islamic Peoples of the Soviet Union, London. Aksoy, Mustafa, "Destanlarda ve Tarihi Kaynaklarda Alper Tunga (Efrasyab)", Türkler, C. III, Ankara, s.554-568.

Altungök, Ahmet, Sâsânîler Dönemi Türk-Fars İlişkileri, (Basılmamış Yüksek Lisans Tezi), Elazığ.

Ambraseys, N. N., A History of Persian Earthquakes, New York

Arrowsmith, Aaron, A Compendium of Ancient and Modern Geography, London.

And Modern Geography: For The Use of Eton School, London. Ayatolahi, Habibolah, The History of Iranian Art, (Trz. Shermin Haghshenas), Tehran.

Bakır, Abdulhalik, Ortaçă̆ İslam Dünyasında Tekstil Sanayi, Giyim-Kuşam ve Moda, Ankara.

Baratova, Larissa, “Orta Asya'daki Türk Kağanlığı (MS. 600800)”, (Çev. Başar Batur), Türkler, Ankara, c. II, s.89-96.

Barthold, W, Tezkire-i Coğrafya-yı Târîh-i Iran, (Trc. Hamza Serdâdver), Tahran.

Barthold, W, "Derbend", MEB İslam Ansiklopedisi, C.3, İstanbul, s.532-533

Barthold, W, “Azerbaycan ve Ermenistan”, (Çev. İsmail Aka), AÜ Dil Tarih Coğrafya Fakültesi Tarih Araştırmaları Dergisi, C. VIII-XII, S. 14-23, s.77-87.

Behnam, Temeddün-i Iranî, Tahran.

Benjamin, S. G. W, Persia, London.

Bilgili, Ali Sinan, “Azerbaycan Türkmenler Tarihi”, Türkler, c. VII, Ankara, s.22-43.

Bilgili, Ali Sinan, “Tebriz”, TDV İslam Ansiklopedisi, c. 40, İstanbul, 2011, s. 219-222.

Bosworth, C. E, "The Political and Dynastic History of the Iranian World", The Cambridge History of Iran: The Saljuq and Mongol Periods, c.5, (Ed. J. A. Boyle) Cambridge, s.1-202. 
Bosworth ve Baynham 2000

Bosworth, C. E; Baynham, E. J, Alexander the Great in Fact and Fiction, Oxford Universty Press, New York.

Boyce vd. 1991 Mary Boyce, Bertold Spuler, Frantz Grenet, Zoroastrianism Under Macedonian and Romen Rule, Leiden.

Brill 1955 Brill, E. J, The Sacrall Kingship, Roma.

Buniyatov 1991 Buniyatov, Musa Ziya, “Azerbaycan”, T.D.V. Islam Ansiklopedisi, İstanbul, c. IV, s.317-322.

Büchner 1966 Büchner, E. A, "Sâsânîler", MEB Íslam Ansiklopedisi, c.5, İstanbul, s.244-248.

Can 1968 Can, Cahit, “Zerdüştlük, Zerdüşt ve Hukuk”, AÜHF Dergisi, c. XXV, s.273-288.

Cavendish 2007 Cavendish, Marshal, Peoples of Western Asia, New York.

Christensen 1993

Chokr 2002

Dalby 2004

Daryaee 2010 Christensen, Peter, The Decline of Iranshahr, Kopenhagen. Chokr, Melhem, İslâm'ın Hicrî İkinci Asrında Zındıklık ve Zındıklar, (Çev. Ayşe Meral), İstanbul.

Dalby, Andrew, Dictionary of Languages, Columbia University Pres.

Daryaee, Touraj, "Bazaars, Merchants, and Trade in Late Antique Iran", Comparative Studies of South Asia, Africa and the Middle East, V.30, No.3, Duke University Pres, s.401-409.

Diakonof 1985 Diakonof, M. M, "Media", The Cambridge History of Iran; The Median and Achaemeian Periods, (Edt. W. B. Fisher; İlya Gersevitch), New York, s.36-148.

Doğan 1992

Druing 2003

Doğan, Sinan, Azerbaycan'ın İktisadî Bünyesi, İstanbul.

Dumper 2007

Druing, Jean, The Spirit of Sounds, Cornwall Boks.

Dumper, Michael, Cities of the Middle East and North Africa, California.

Ebu Yusuf 1982

Elgood 2010

Ebu Yusuf, Kitâbu'l-Harâc, (Trc. Müderriszâde Muhammed Atâullah, nşr. İsmail Karakaya), Ankara.

Faysal (Trz)

Fisher 1978

Furon 1943

Garthwaite 2005

Girişmen 1336hş

Gömeç 1999

Elgood, Cyril, A Medical History of Persia and the Eastern Caliphate, New York.

Faysal, Şukri, Hareketü'l-Fethi'l-İslâmi, Beyrut.

Fisher, W. B, "Physical Geographia", The Cambridge History of Iran, V. I, (Edt. W. B. Fisher), New York, s.3-110.

Furon, Raymond, Iran, (Çev. G. K. Söylemezoğlu), İstanbul.

Garthwaite, Gene R, The Persians, Blakwell Publishing.

Girişmen, R., Iran ez Agaz ta Íslam, (Trc. Muhammed Mu'in), Tahran.

Gömeç, Saadettin, Türk Cumhuriyetleri ve Topluluklart Tarihi, Ankara. 
Greatrex ve Lieu 2002 Greatrex, G. -Lieu, S. N. C., The Roman Eastern Frontier and the Persian Wars, V. II, London.

Grenard 1992

Grenard, Fernand, Asya'nın Yükselişi ve Düşüşü, (Çev. Orhan Yüksel), İstanbul.

Gurbanov 2007

Gurbanov, Abbas, Abbasilerin Ilk Yıllarında Azerbaycan, (S.Ü. Basılmamış Doktora Tezi), Konya.

Gündüz 2003

Gündüz, Şinasi, "Mecûsîlik", TDV. İslam Ansiklopedisi, C. XXVIII, Ankara, s.279-284.

Grousset 2006

Grousset, Rene, Başlangıcından 1071'e Ermenilerin Tarihi, (Çev. Sosi Dolanoğlu), İstanbul.

Hamaçî 1370hş

Hamidullah 1985

Hamaçî, Behruz, Ferheng-i Coğrafyay-ı Azerbaycan-ı Şarkî, Tahran.

Has 2004

Hattab 1998

Henrichs 1979

Hamidullah, Muhammed, Mecmû'atu'l-Vesâiki's-Siyâsiyye li'l-Ahdi'n-Nebevî ve'l-Hilâfeti'r-Râşide, Beyrut.

Has, Kenan, "Mezdekiye", T.D.V. İslam Ansiklopedisi, c.29, Ankara, s.523-524.

Hattab, Mahmud Şit, Kâdetü Fethi's-Sind ve Afganistan, Beyrut.

Henrichs, Albert, "The Cologne Mani Codex Reconsidered" Harvard Studies in Classical Philology, V. 83, Harvard Press, s.339-367.

Herodotos 1991 Herodotos, Herodot Tarihi, (Trc. Müntekim Ökmen), Remzi Kitabevi, İstanbul.

Horenatsi $1380 \mathrm{hş} \quad$ Horenatsi, Moses, Tarih-i Ermenistan, (Trc. Edik Bağdasaryan), Tahran.

Houtsma 1936

Houtsma, M. T, “Adharbaidjan”, E. J. Brill's First Encyclopaedia of Islam 1913-1936, c.I, Leiden, s.134-138.

Houtsma 1987 Houtsma, M. T, "Urmiya”, E J Birll's First Ancyclopaedia of Íslam 1913-1936, c.VIII, Leiden, s.1032-1038.

Houtsma $1993 \quad$ Houtsma, M. T, “Tabriz”, E. J. Brill's First Encyclopaedia of Islam 1913-1936, c.VIII, Leiden, s.426-430.

Huart 1963 Huart, C, "Deri/Dari”, MEB İslam Ansiklopedisi, C. 3, İstanbul, s.542.

İbnu'l-Belhî 1339hş İbnu'l-Belhi, Farsname, (Tsh. Guy Le Strenge; Reynold Elen Nikolsen), Tahran.

İbnu'l-Belhî 2008 İbnu'l-Belhî, "Farsnâme”, (Çev. Abdulhalik Bakır, Ahmet Altungök), Ortaçă̆ Tarih ve Medeniyetine Dair Çeviriler I, Ankara, s.23-148.

İbnu'l-Esîr (Trz) İbnu'l-Esîr, el-Kâmil fi 't-Târih, Beyrut, (Trz.), c. I.

İbn Haldun 1996 İbn Haldun, Mukaddime, C. 2, Ankara.

İbnu'l-Havkal 1338hş İbnu'l-Havkal, Suret'ü-l Arz, (Trc. Cafer Şiar), Tahran.

İstahrî 1997

İstahrî, Mesâlikü'l-Memâlik, Beyrut. 
Jackson 1906

Jonston 2006

Karahan (Trz)

Kazvinî 1960

Kıristensen 1368hş

Kister 2008

Khoi (Trz)

Konukçu 1973

Leeuw 2000

Ligeti 1998

Ludwing (Trz)

Madelung 1975

Malcolm 1806

Mann 1932

Marşak 2002

Memmedova 1993

Minahan 2000

Melville 1981

Meşkür 1366hş

Minorsky 1957

Minorsky $1337 \mathrm{hş}$

Minorsky 1964
Jackson, A. V. Williams, Persia Past and Present, London. Jonston, James Howard, East Rome, Sâsânîn Persia and the End of Antiquity, Hampshire.

Karahan, Abdulkadir, "Firdevsiye Göre İran Eski Tarihi ve Şahname'nin Kaynakları” Iran Şehinşahlığının 2500. Kuruluş Ylldönümüne Armă̆an, MEB Yay. s.195-210.

Kazvinî, Zekeriya Muhammed, Âsâru'l-Bilâd ve Ahbâru'lIbâd, Beyrut.

Kuristensen, Artur, Iran der Zaman-i Sâsânîyan, (Trc. Raşid Yasmi), Tahran.

Kister, M. J, “el-Hire Arabistan’a İlişkin Bazı Notlar”, (Çev. Abdulhalik Bakır; Gülşen Karabulut), Ortaçă̆ Tarih ve Medeniyetine Dair çeviriler II, Ankara.

Khoi, Riyahi; Mohammad Amin, "Molahazey-i der barey-i Zeban-i Kohen-i Azerbaycan”, Ittilaat-i İktisadi, s.180-181.

Konukçu, Enver, Kuşan ve Akhun Tarihi, Ankara.

Leeuw, Charles van der, Azerbaijan: A Quest For Identıty, A Short History, St. Martin Pres, New York.

Lajos Ligeti, Bilinmeyen Iç Asya, Ankara: TTK Yayınevi.

Ludwing, Paul, "The Position of Zazaki Among West Iranian Languages", Iran Araştırmaları 3. Avrupa Konferansı Tebliğ Metni, s.163-176.

Madelung, W, "The Minor Dynasties of Northern Iran", The Cambridge History of Iran 4; From the Arab Invasion to the Saljuqs, New York, s.198-249.

Malcolm, Sir John, The History of Persia from the Most Early Period to Present Time, V. I, London.

Mann, Oscar, Mundarten der Zaza, Berlin.

Marşak, Boris, "Türkler ve Soğdlular”, (Çev. Alesker Aleskerov), Türkler C. II, Ankara, s.170-177.

Memmedova, Feride, Azerbaycan'ın Siyasi Tarihi ve Tarihi Coğrafyası, Bakü.

Minahan, James, Miniature Empires, London?.

Melville, Charles, "Historical Monuments and Earthquakes in Tabriz", Iran, XIX, s.159-178.

Meşkür, Cevad, Tarih-i İran Zemin, Tahran.

Minorsky, V, Studies in Caucasian History, Cambridge Universty Pres, Cambridge.

Minorsky, V, Tarih-i Tebriz, (Trc. Abdu'l-Ali Kareng), Tebriz Minorsky, V, "Roman and Byzantine campaigns in Atropatene", Iranica, Publications of the University of Tehran 775, Tehran, s. 86-109. 
Minorsky 1965

Minorsky vd. 2007

Mignan 1834

Morony 1976

Minorsky, V, "Tebriz", İslam Ansiklopedisi, İstanbul, c. 12/1, s. 82-85.

Mütercim Asım Efendi 2000

Minorsky, V., C. E. Bosworth, Sheila S. Blair, "Tabriz", Historic Cities of the Islamic World, (Edt. C. E. Bosworth), Leiden, s.486-498.

Mignan, R, "Georgia, Persia and Mesopotamia", Journal of the Asiatic Society of Bengal, III, s.576-589.

Michael G. Morony, "The Effects of The Muslim Conquest On The Persian Population of Iraq"' Iran 14, s.41-60.

Mütercim Asım Efendi, Burhan-ı Katı, (Haz.: Mürsel Öztürk, Derya Örs), Ankara, 2000.

Naroditskaya 2002

Naroditskaya, Inna, Song from the Land of Fire, New York.

Nas1-1 Hüsrev 1950 Nasır-1 Hüsrev, Sefername, (Çev. Abdülvehap Tarzi), İstanbul.

Nefisi 1331 hş

Nicole 1996

Oseley 1825

Öztuna 1977

Porter 1822

P'yankov 2002

Rawlinson 2005

Rawlinson, 1841

Riza 1376hş

Reisneya (Trz)

Rossabi 2010

Rudolph 2002

Schippmann 1989 Nefisi, Said, Tarih-i Temeddün-i Iran-i Sasan, Tahran, 1331. Nicole, David, Sassanian Armies: the Iranian Empire Early 3rd to mid-7th centuries AD, Montvert, 1996.

Oseley, William, Travels in Various Countries of the East, More Particularly Persia, V. 3, London, 1825.

Öztuna, Yılmaz, Büyük Türkiye Tarihi, İstanbul.

Porter, Sir Robert K, Travels in Georgia, Persia, Armenia, Ancient Babylonia, London.

P'yankov, Igor, "Sakalar", (Çev. Zülfiye Veliyeva), Türkler C. I, Ankara, s.611-619.

Rawlinson, George, The Seven Great Monarchies of the Ancient Eastern World: The Seventh Monarchy: History of the Sassanian or New Persian Empire, Indy Publish.

Rawlinson, H. C., "the Atropatenian Ecbatana", The Journal of the Royal Geographical Society of London X, (Edt.: John Murray) London, 1841, s.65-158.

Rıza, İnayetullah, Iran ve Turkan der Zaman-ı Sâsânîyan, Tahran.

Reisneya, Rahim, Azerbaycan der Seyri Tarih-i Iran, Tahran

Rossabi, Morris, "Tabriz and Yuan China", East Asian Maritime History 10; Aspects of the Maritime Silk Road: From the Persian Gulf to the East China Sea, (Edt. Ralph Kauz), Wiesbaden, s.97-106.

Rudolph, Kurt, "Maniheizm”, (Çev. Mustafa Bıyık), Gazi Üniversitesi Çorum Ilahiyat Fakültesi Dergisi, 2002/I, s.378-393

Schippmann, K, "Azerbaijan III. Pre-İslamic History", Encyclopaedia Iranica, Columbia University, c.III, s.221-224. 


\section{Erken Ortaçă̆larda Tebriz}

Sinor 2002

Smith 1833

Strange 2011

Sümer 1994

Syme ve Birley 2003

Taylor 1870

Tefazzulî 1995

Togan 1942

Togan 1970

Tyrwhitt 1868

Turan 2008

Turan 1965

Ünal 1975

Vaux 1900

Yazıc1 2004

Yildız 1991

Yumanadi 2002

Yücel 2002

ez-Zâbit 1984

Zehtabî (Trz)

Zettersteen 1986

Wiesehöfer 2003

Wilson 1930
Sinor, Denis, Türk Imparatorluğunun Kuruluşu ve Yıkılışı, (Çev. Talat Tekin), İstanbul.

Smith, Eli, Researches in Armenia; Including a Journey Through Asia Minor and into Georgia and Persia, V. I, Boston.

Strange, Guy Le, The Lands of Eastern Caliphate, New York.

Sümer, Faruk, "Dihkan”, T.D.V. İslam Ansiklopedisi, İstanbul, c. IX, s.289-290.

Ronald Syme - A. Richard Birley, Anatolica: Studies in Strabo, New York.

Taylor, William Cooke, The Student's Manual of Ancient History, London.

Tefazzulî, Ahmet, "Enuşirvan", T.D.V. İslam Ansiklopedisi, İstanbul, c. XI, s.255.

Togan, A. Z. V., Bugünkü Türk ili (Türkistan) ve Yakın Tarihi, İstanbul.

Togan, A. Z. V., “Azerbaycan”, MEB İslam Ansiklopedisi, c. II, İstanbul, s.91-118.

Tyrwhitt, R. Edmund, Esther and Ahasuerus, London.

Turan, Lokman, "Yenişehirli Avni Efendinin Ateşgede Mesnevisi Üzerine Bir İnceleme", Literatur and History of Turkish, V 3/4, Summer, s.866-903.

Turan, Osman, Selçuklu Tarihi ve Türk-İslam Medeniyeti, Ankara.

Ünal, Tahsin, Türk'ün Sosyo-Ekonomik Tarihi, Konya.

Vaux, W. S. Wright, Nineveh and Persepolis, London.

Yazıcı, Tahsin, "Merzüban", T.D.V. Islam Ansiklopedisi, Ankara, c. XXIX, s.255-256.

Yıldız, Hakkı Dursun, "Bâbek", T.D.V. Íslam Ansiklopedisi, İstanbul, c. IV, s.376-377.

Yumanadi, Y K, "Hazarlar", Türkler, C. 2, Ankara, s.464-472.

Yücel, Mualla Uydu, "Hazar Hakanlığg”, Türkler, C. II, Ankara, s.445-463.

ez-Zâbit, Şâkir Sabır, Târihu'l-Münâza'ât ve'l-Hurûb Beyne'lIrâk ve Iran, Bağdat.

Zehtabi, M. T, Iran Türkleri'nin Eski Tarihi, C. I-II, Tebriz.

Zettersteen, K U, "Zübeyde", MEB İslam Ansiklopedisi, C.13, İstanbul, s.634.

Wiesehöfer, Josef, Antik Pers Tarihi, (Çev. Mehmet Ali İnci), İstanbul.

Wilson, Arnold T, "Earthquakes in Persia", Bulletin of the School of Oriental Studies, Vol. 6, No. I. s.103-131. 
Abdulhalik Bakır - Ahmet Altungök 